\author{
Contato \\ ICHS - UFOP \\ Rua do Seminário, s/n \\ 35420-000 - Mariana - Minas Gerais \\ E-mail: mantoniosilveira@yahoo.com.br
}

\section{HISTÓRIA E POLÍTICA: \\ A HISTORIOGRAFIA COLONIAL ENTRE A CRÍTICA E A RESPONSABILIDADE (1989-2010)}

\author{
Marco Antonio Silveira* \\ Universidade Federal de Ouro Preto
}

\title{
Resumo
}

Este artigo objetiva levantar questões acerca de alguns dos debates travados pela historiografia colonial brasileira nas últimas duas décadas, relacionando-as, em linhas gerais, com mudanças políticas e sociais ocorridas no Brasil. Sugere-se que, no cerne de tais debates, encontra-se um mal-estar atinente às formas pelas quais os historiadores lidam com o problema da responsabilidade diante de uma sociedade marcadamente desigual.

\section{Palavras-chave}

Política - historiografia - universidade.

\footnotetext{
* Professor adjunto da Universidade Federal de Ouro Preto, doutor pela Universidade de São Paulo e bolsista de Produtividade em Pesquisa - CNPq. Dedico este artigo a todos os professores que se esforçaram pela minha formação.
} 


\section{HISTORY AND \\ POLITICS: THE \\ COLONIAL}

HISTORIOGRAPHY

BETWEEN THE

CRITICISM AND THE

RESPONSIBILITY

(1989-2010)

Contact

ICHS - UFOP

Rua do Seminário, s/n

35420-000 - Mariana - Minas Gerais

E-mail: mantoniosilveira@yahoo.com.br

Marco Antonio Silveira

Universidade Federal de Ouro Preto

\section{Abstract}

This paper aims to raise some questions about the debates made by the Brazilian colonial historiography in the last two decades, relating them in general to the political and social changes happened in Brazil. It is suggested that in the heart of these debates it is the problem of the responsibility as to a very inequal society.

\section{Keywords}

Politics - historiography - university. 
REVISTA DE HISTÓRIA

SÃO PAULO, N ${ }^{\circ} 169$, p. 255-290,

JULHO / DEZEMBRO 2013
Marco Antonio Silveira

História e política: a historiografia colonial entre a crítica e a responsabilidade $(1989-2010)$

Os inimigos nos olharão com desprezo: coitado, dirão, até hoje ainda falando de tudo isso. E os traços da aventura menor já foram talvez até apagados dos arquivos, borrados dos anais e certamente suplantados por milhares de outras histórias mais excitantes que se repetem diuturnamente e eu aqui insistindo sobre tão insignificantes eventos, querendo me fazer de importante, buscando talvez a compaixão das donzelas, enfurecido por distinguir-me na exibição das minhas chagas, dedo em não riste, não riam, por favor, pois a dor é séria.

Luiz Roberto Salinas Fortes. Retrato calado. 1988.

\section{Historiografia e política}

Durante os vinte e dois anos que transcorreram entre 1989 e 2010, as mudanças na historiografia brasileira, em particular naquela voltada ao estudo das sociedades coloniais da América portuguesa, acompanharam oscilações decisivas nas relações sociais, políticas e econômicas do Brasil e do mundo. As relações entre a trajetória do discurso historiográfico e as tensões em torno dos modos de organização da sociedade brasileira não se deram, evidentemente, sob a forma do simples reflexo. Uma visão desse tipo levaria à hipótese de que os historiadores tendem a subordinar passivamente as reflexões comuns a sua área de estudo às concepções preponderantes no momento em que escrevem. De fato, seria difícil sustentar uma investigação calcada no pressuposto de que o discurso historiográfico reproduziria passivamente, em vocabulário técnico próprio, o pensamento hegemônico de sua sociedade - que, por sua vez, refletiria as condições políticas, econômicas e sociais vigentes. Afinal, os diferentes tipos de linguagem, ao traduzirem-se reciprocamente e modificarem-se uns aos outros, abrem-se a possibilidades variadas de ressignificação.

Seguindo tal perspectiva, é importante questionar se e de que modo o léxico e os enunciados fundamentais do discurso historiográfico modificaram-se nas últimas décadas. Essa questão, pela sua amplitude, demanda um recorte. Assim, é referida aqui a relação entre, por um lado, os regimes discursivos praticados por acadêmicos - a despeito de sua diversidade de formas e conteúdos - e, por outro, as mudanças de ordenamento das estruturas sociais e econômicas do Brasil ocorridas durante os governos de Fernando Henrique Cardoso (1995-2002) e Luiz Inácio Lula da Silva (2002-2010). Em outras palavras, o problema que se busca esboçar pode ser formulado do seguinte modo: de que maneira o discurso historiográfico e o debate político se relacionaram num período histórico caracterizado pela renovação dos embates em torno de temas como o do desenvolvimento e da desigualdade no Brasil? O objetivo deste artigo não é o de fazer um balanço dos debates ocorridos no interior da historiografia brasileira durante o período indicado, mas, sim, 
o de destacar certos aspectos políticos que atravessam a atuação dos historiadores. Daí o fato de serem privilegiados, como fontes, apresentações orais, registros de debates públicos e entrevistas concedidas a jornais. ${ }^{1}$ Almeja-se, nesse sentido, relacionar a adoção de certa perspectiva historiográfica referente às sociedades coloniais - em especial aquela que destaca os mecanismos de adesão a ordem - às mudanças políticas, institucionais e acadêmicas ocorridas no Brasil desde 1989, chamando-se a atenção para a possibilidade de que concepções conservadoras tenham impactado as formas de investigação exercidas pelos historiadores. Em que medida a constante retomada de argumentos relativos à adesão a ordem tende a desprezar a multiplicidade de sentidos existentes numa sociedade, inclusive aqueles atinentes ao sofrimento corporal e psíquico dos indivíduos? A emergência de tais argumentos na historiografia está relacionada às mudanças políticas ocorridas nas últimas décadas? Não se trata, pois, de um artigo voltado ao estudo da escravidão, do marxismo ou da violência, ainda que esses temas atravessem a reflexão.

Em linhas bastante gerais, é possível afirmar que, entre professores e estudantes universitários dedicados à compreensão da história, o debate dos últimos decênios foi caracterizado em boa medida pela problematização da herança marxista. Esse fenômeno, é claro, não se ateve ao Brasil, nem era propriamente novo. ${ }^{2}$ No início da década de 1990, após a queda do Muro de Berlim e da decretação do fim da Guerra Fria, lidar com essa herança tornou-se aspecto importante para uma historiografia em expansão institucional e capacitada para absorver positivamente as inovações de pensamento oriundas de matrizes diversas. Como já foi descrito inúmeras vezes, os historiadores acolheram as inovações ocorridas no interior do próprio marxismo - em es-

\footnotetext{
${ }^{1}$ Uma investigação exaustiva da relação entre política e historiografia demandaria desdobramentos complexos, especialmente sobre a história intelectual e a história das elites, que não podem ser realizados nos limites deste artigo. Mesmo no recorte adotado e expresso nas páginas a seguir, tornam-se evidentes algumas ausências decisivas, especialmente a do historiador Luiz Felipe de Alencastro, cuja atuação, especialmente na última década, tem ultrapassado os limites universitários e alcançado as páginas dos periódicos. A reflexão esboçada neste artigo, que carece também de uma discussão mais cuidadosa capaz de explicitar os princípios que o norteiam, consiste num esforço de caráter introdutório cujo objetivo é mais o de levantar questões do que o de tratá-las da maneira devidamente aprofundada.

2 Dois exemplos de tratamento ao mesmo tempo crítico e respeitoso da herança marxista encontram-se em ARENDT, Hannah. A condição humana. Tradução. Rio de Janeiro: Forense-Universitária, Salamandra; São Paulo: Editora Universidade de São Paulo, 1984, livro publicado originalmente em 1958; e em DERRIDA, Jacques. Espectros de Marx. Tradução. Rio de Janeiro: Relume-Dumará, 1994. Obra resultante de conferência realizada em 1993.
} 
REVISTA DE HISTÓRIA

SÃO PAULO, N ${ }^{\circ} 169$, p. 255-290,

JULHO / DEZEMBRO 2013
Marco Antonio Silveira

História e política: a historiografia colonial entre a crítica e a responsabilidade (1989-2010)

pecial de sua nova vertente inglesa -, as contribuições advindas dos diversos momentos experimentados pelos historiadores dos Annales, as propostas da chamada História cultural, as possibilidades abertas pela micro-história, os pressupostos teórico-metodológicos de disciplinas tais como a Antropologia e a Sociologia, os complexos textos da filosofia pós-estruturalista francesa, e os estudos cada vez mais sofisticados sobre linguagem e narrativa. Desse emaranhado de trilhas percorridas reforçaram-se as críticas àqueles que seriam os grandes perigos de certas abordagens de matriz marxista: o determinismo, o estruturalismo, a noção de falsa consciência, a teleologia e o anacronismo.

No Brasil, como também em outros lugares da América Latina, a complexificação do debate historiográfico apresentou um desdobramento nada casual: embora os historiadores fossem se afastando gradualmente do legado de Marx - ou pelo menos pensassem fazê-lo -, o debate político a respeito do modelo econômico a ser adotado no país permaneceu, explicitamente ou não, atravessado pelo tema da luta de classes. Nesse sentido, como os historiadores concatenaram a prática do ofício com o modo de analisar os dilemas políticos da sociedade em que viviam? Haveria alguma tendência de se abraçar certo antimarxismo nos gabinetes e, ao mesmo tempo, recorrer ao velho pensador alemão, ainda que seletivamente, em busca de meios para se entender a situação do país? Haveria, entre os universitários, uma recusa frente à elaboração de modelos estruturais - por estes serem considerados potencialmente teleológicos -, seguida, logo depois, já nas ruas e fora do campus, de uma aceitação de explicações classistas sobre a reprodução da desigualdade e os empecilhos ao desenvolvimento? Seria correta a hipótese de que muitos intelectuais brasileiros, sem se darem conta disso, tornaram-se marxistas sem Marx?

De forma esquemática e despretensiosa, aventa-se que a sociedade brasileira experimentou, nas últimas décadas, três momentos diferentes. Entre 1979, ano da aprovação da anistia, e 1989 - quando, um ano depois do fim da Constituinte, deu-se, enfim, a primeira eleição direta para presidente -, a politização foi crescente. Apesar de, nesse período, os governos de Margaret Thatcher, na Inglaterra, e Ronald Reagan, nos Estados Unidos, começarem a deixar sua marca por meio da valorização do ideário neoliberal, a luta contra a ditadura, a articulação de setores de esquerda em torno do Partido dos Trabalhadores (PT) e da Central Única dos Trabalhadores (CUT), e a força da tradição desenvolvimentista entre os economistas colocaram limites à sua penetração no Brasil. Contudo, após o fracasso do Plano Cruzado em 198687, a queda do Muro de Berlim em 1989, e a eleição de Fernando Collor no mesmo ano, as ideias neoliberais iniciaram de forma efetiva seu trajeto na história do país, dando início a outro momento que, superando a aparente 
REVISTA DE HISTÓRIA

SÃO PAULO, N 169 , p. 255-290,

JULHO / DEZEMBRO 2013
Marco Antonio Silveira

História e política: a historiografia colonial entre a crítica e a responsabilidade (1989-2010)

retomada da politização resultante do impeachment, caracterizou-se pela desmobilização do governo de Fernando Henrique Cardoso e de seu Partido da Social Democracia Brasileira (PSDB). ${ }^{3}$ Por fim, com a vitória de Lula nas eleições de 2002, e apesar da retomada do receituário definido por juros altos, superávit primário e metas de inflação, passa a ser gestado um período de reformismo gradual em que o esforço de equilibrar estratégias neoliberais com uma política de diminuição acentuada da pobreza - embora não da desigualdade - produziu certa acomodação. ${ }^{4}$ Dentre esses três períodos - que não devem ser tomados como expressão de fenômenos lineares -, aqui são privilegiados os dois últimos, de desmobilização e acomodação, com o intento de se refletir sobre como se constituíram as relações entre discurso historiográfico e debates políticos.

\section{Violência}

Nos intrincados embates envolvendo historiografia e política na passagem para o século XXI, o tema da escravidão assumiu um papel central. A conjugação da crise do marxismo, entre os historiadores brasileiros, com a emergência, no país, das receitas neoliberais produziu um ambiente de nitroglicerina pura. Em dezembro de 1991, um seminário organizado na Universidade Federal de Ouro Preto (Ufop), intitulado "Tendências contemporâneas da historiografia brasileira", sinalizou o clima de tensão. Ao contar com a presença de Luís Carlos Soares, Luís Mott, Sílvia Lara e Jacob Gorender, o seminário retomava as rusgas provocadas pela publicação de trabalhos de alguns historiadores da Universidade Estadual de Campinas (Unicamp). O evento ocorreu num momento particularmente intenso, no qual os conflitos já haviam alcançado a imprensa. ${ }^{5} \mathrm{O}$ cerne da discussão consistia em estimar

\footnotetext{
3 Cf. FILGUEIRAS, Luiz. O neoliberalismo no Brasil: estrutura, dinâmica e ajuste de modelo econômico. In: BASUALDO, Eduardo M. e ARCEO, Enrique (org.). Neoliberalismo y sectores dominantes. Tendencias globales y experiencias nacionales. Buenos Aires: Clacso, 2006, p. 178-206. Segundo o autor, a partir do governo Collor deu-se um "claro enfraquecimento da capacidade política e de negociação da classe trabalhadora e de suas representações".

${ }^{4}$ Cf., sobre o governo Lula, ANDERSON, Perry. O Brasil de Lula. Novos Estudos, n. 9, novembro de 2011, p. 23-52; e SINGER, André. Os sentidos do lulismo. Reforma gradual e pacto conservador. São Paulo: Companhia das Letras, 2012.

${ }^{5}$ Certamente, um ponto de inflexão no debate resultou da publicação do livro de GORENDER, Jacob. A escravidão reabilitada. São Paulo: Ártica, 1990. Em 24 de novembro de 1990, Sidney Chalhoub publicou, na Folha de S. Paulo, uma resposta às críticas do autor em artigo intitulado "Gorender põe etiquetas nos historiadores". Gorender, por sua vez, publicou no mesmo jornal,
} 
REVISTA DE HISTÓRIA

SÃO PAULO, N ${ }^{\circ} 169$, p. 255-290,

JULHO / DEZEMBRO 2013
Marco Antonio Silveira

História e política: a historiografia colonial entre a crítica e a responsabilidade (1989-2010)

a justiça ou a injustiça da afirmação de Gorender, para quem autores como Silvia Lara e Sidney Chalhoub buscavam reabilitar a escravidão através de suas obras. O substantivo reabilitação não deixava margem a dúvidas quanto à acusação do militante comunista dirigida à nova geração de historiadores, já que o Aurélio atribuía dois significados principais ao verbo reabilitar: "restituir ao estado anterior, aos primeiros direitos, prerrogativas etc."; e "restituir à estima pública ou à particular". Por certo a acusação de Gorender dizia respeito a este último sentido. Porém, os dois significados do vocábulo como, aliás, não passou despercebido a Silvia Lara - apontavam para uma incômoda ambiguidade, pois traziam à tona as práticas autocráticas vigentes entre os comunistas, que ora renegavam alguns colegas e os punham no ostracismo, ora os reabilitavam. Essa ambiguidade explicitava que o conflito não se restringia ao campo das discussões historiográficas, alcançando também o problema da validade ou incoerência das práticas da velha esquerda.

Nesse sentido, chama a atenção que, em sua conferência, Silvia Lara tenha feito questão de destacar um aspecto crucial: "Este é, evidentemente, um debate político. Não um debate entre direita e esquerda, como querem fazer crer alguns, mas um debate no interior das esquerdas". ${ }^{6}$ Mais ainda, respondendo a uma pergunta que lhe fora feita pela plateia ao fim de sua fala, afirmou: "Não creio que a politização do debate teórico seja perniciosa, mesmo porque não sei como fazer um debate teórico sem fazer política"7 Provavelmente, poucos historiadores hoje discordariam da existência de vínculos entre discurso e poder ou da dimensão política da narrativa historiográfica. Contudo, as palavras da conferencista geram certo mal-estar. No momento em que foram proferidas, pouco tempo depois da disputada eleição de 1989, e pouco antes do impeachment de Collor, a marca da politização da sociedade se fazia ainda sentir. Estava-se relativamente distante - não propriamente em termos de anos, mas de mudança histórica - da dura repressão contra os petroleiros efetuada, em 1995, pelo presidente Fernando Henrique Cardoso. Se a hipótese de que os anos seguintes foram caracterizados por desmobilização e acomodação procede, vale questionar se os atuais professores e estudantes dos departamentos de História levariam de fato a sério as afirmações

em 15 de dezembro, um texto provocativamente intitulado "Como era bom ser escravo no Brasil". Em 12 de janeiro do ano seguinte, também na Folha, Silvia Lara retrucou com "Gorender escraviza a história".

6 LARA, Silvia. Escravidão no Brasil: um balanço historiográfico. LPH. Revista de História, v. 3, n. 1, 1992, p. 230. O grifo consta do texto original.

7 LARA, Silvia. Escravidãono Brasil:umbalanço historiográfico.LPH.Revista deHistória, v.3, n. 1, 1992, p. 234. 
REVISTA DE HISTÓRIA

SÃO PAULO, N 169 , p. 255-290,

JULHO / DEZEMBRO 2013
Marco Antonio Silveira

História e política: a historiografia colonial entre a crítica e a responsabilidade (1989-2010)

de Silvia Lara. Não se trata aqui de dizer que o debate universitário tem de ocorrer nos limites traçados pelo pensamento de esquerda. Trata-se, sim, de indagar, de um lado, se os historiadores ainda acreditam que seu trabalho implica algum engajamento político e, de outro, se o próprio significado de esquerda não mudou. Se o PT da década de 1980 não é mais o PT da década de 2010, e se o PSDB desvencilhou-se rapidamente de sua aura ilustrada, os professores universitários, politicamente falando, seriam os mesmos?

Uma formulação dessa espécie pode conduzir a análise rumo a visões estereotipadas relativas à oposição entre reforma e revolução. O próprio contraponto parece hoje deslocado e sem grande capacidade de apelo. Seja como for, a reflexão sobre a atualização dos modos de superar as injustiças da sociedade brasileira já estava claramente colocada na época do seminário da Ufop. Uma edição da Revista Brasileira de História de 1991 apresentava na capa o título "Reforma e Revolução". Já no primeiro artigo, Marco Aurélio Garcia - que depois viria a ocupar papel importante no governo Lula - propunha-se a resgatar a trajetória de ambos os termos "no movimento operário e socialista internacionais do final do século XIX e começos do século XX". E no resumo assinalava: "O autor conclui que na sua formulação original a disjuntiva reforma/revolução é peça de museu". ${ }^{8}$ No mesmo número, Edgar de Decca, em artigo sugestivamente chamado "A revolução acabou", concluía suas reflexões com as seguintes palavras:

Na historiografia dos anos oitenta, a revolução passou por uma profunda revisão e as ques-
tões pertinentes ao contexto dos anos sessenta perderam a sua força de atração. Daquele
imaginário que empolgou setores significativos das sociedades em escala mundial, talvez
os ideais da revolta e da rebelião ainda permaneçam vivos. A presença deste imaginário,
pelo menos em termos de nossa experiência política, provavelmente, deve-se ao fato de
que viemos a descobrir que em matéria de cidadania os mais amplos setores da sociedade
brasileira são os rebeldes primitivos de que falaram Hobsbawm e Edward Thompson.

São palavras instigantes quando analisadas do ponto de vista de quem assistiu posteriormente à emergência do lulismo. Que relação haveria entre os rebeldes primitivos apontados por Edgar de Decca e o subproletariado que, na interpretação de André Singer, constitui a mais importante base de

\footnotetext{
${ }^{8}$ GARCIA, Marco Aurélio. Reforma e revolução/reforma ou revolução (Discussão de um pradigma). Revista Brasileira de História. São Paulo, v. 10, n. 20, 1991, p. 9 (Reforma e Revolução).

9 DE DECCA, Edgar. A revolução acabou. Revista Brasileira de História. São Paulo, v. 10, n. 20, 1991, p. 73-4 (Reforma e Revolução). Grifo meu.
} 
REVISTA DE HISTÓRIA

SÃO PAULO, N ${ }^{\circ} 169$, p. 255-290,

JULHO / DEZEMBRO 2013
Marco Antonio Silveira

História e política: a historiografia colonial entre a crítica e a responsabilidade (1989-2010)

apoio dos governos petistas em razão de suas políticas bem-sucedidas de erradicação da miséria? Mas outro ponto chama a atenção no trecho citado acima: o uso da palavra revisão. A menção a Eric Hobsbawm e a Edward Thompson remete ao esforço de um grupo de influentes marxistas ingleses de rever criticamente perspectivas dogmáticas e aproximar-se da noção de democracia. Revisão tem, nesse contexto, um sentido positivo, apartando-se, portanto, da conotação negativa da expressão revisionismo.

Na conferência que ministrou no seminário ufopiano, Jacob Gorender destacou de maneira introdutória a ocorrência, "em escala mundial", "no nosso mundo ocidental", do que ele definiu como uma "historiografia das reabilitações".10 Dela tomariam parte a negação da Revolução Francesa, a suavização do Santo Ofício e uma "reabilitação do nazismo", cujo principal expoente era o historiador Ernst Nolte:

Nolte lembrou o massacre dos indígenas, aqui nas Américas, de negros nas Áfricas, para justificar o massacre nos campos de concentração que continuaram até quase o fim, ou até quase o momento da derrota completa do nazismo, como ato de defesa da nação alemã contra a agressão judaica e o que seria o domínio dos russos com toda sua crueldade. ${ }^{11}$

Haveria, ademais, uma reabilitação do czarismo na extinta União Soviética, bem como "a reabilitação da colonização ibérica no continente americano". ${ }^{12}$ E concluía:

Aqui, o meu propósito é o de localizar uma específica reabilitação que é a brasileira, objeto, como vocês sabem, de um livro que eu escrevi e [foi] publicado pela editora Ática, o ano passado. Trata-se da reabilitação da escravidão. ${ }^{13}$

Parece claro que, para Gorender, a apropriação da historiografia marxista inglesa não implicava revisão, mas revisionismo - ainda que o termo utilizado pelo autor fosse reabilitação. Nesse sentido, sua conferência trazia uma contradição perturbadora. Se, de uma parte, o autor criticava o revisionismo alemão por valer-se do massacre de indígenas e africanos para justificar o massacre nazista, de outra, ao associar os vários tipos de reabilitação descritos numa mesma historiografia - a "historiografia das reabilitações" -, acabava por efetuar a mesma operação: Silvia Lara e Ernst Nolte teriam algo em

\footnotetext{
${ }^{10}$ GORENDER, Jacob. A escravidão reabilitada. LPH. Revista de História, v. 3, n. 1, 1992, p. 245.

${ }^{11}$ GORENDER, Jacob. A escravidão reabilitada. LPH. Revista de História, v. 3, n. 1, 1992, p. 246

${ }^{12}$ GORENDER, Jacob. A escravidão reabilitada. LPH. Revista de História, v. 3, n. 1, 1992, p. 247.

${ }^{13}$ GORENDER, Jacob. A escravidão reabilitada. LPH. Revista de História, v. 3, n. 1, 1992, p. 247.
} 
REVISTA DE HISTÓRIA

SÃO PAULO, N 169 , p. 255-290,

JULHO / DEZEMBRO 2013
Marco Antonio Silveira

História e política: a historiografia colonial entre a crítica e a responsabilidade (1989-2010)

comum. Evidentemente, a associação de historiadores brasileiros, como Lara e Chalhoub, com alguém que, em alguma medida, procura justificar a Shoah constitui de fato algo inadequado. Não importa se Gorender teve ou não consciência dessa contradição - a comparação é inaceitável. Para além de seu caráter ofensivo, ela produz o efeito perverso de paradoxalmente justificar o que Hannah Arendt chamou de "banalidade do mal". ${ }^{4}$ Sabe-se que a autora alemã cunhou a expressão para se referir, por ocasião do julgamento de Adolf Eichmann, à realização subserviente de atos de incrível atrocidade em nome da obrigação de cumprir ordens ou do desejo de fazer carreira e ser reconhecido como um bom funcionário. Retirar da Shoah sua especificidade, definindo-a como simples exemplo de uma história de massacres, tende a reforçar essa banalização e a esvaziar a dura experiência vivida por quem passou por campos de concentração ou câmaras de gás. Ao aproximar, através do termo "reabilitação", a escravidão americana e o extermínio nazista, Gorender, mesmo sem o querer, deu à banalidade do mal sua própria contribuição.

Sobre essa espinhosa questão, o historiador Temístocles Cezar retoma a resposta de Jurgen Habermas aos revisionistas:

Habermas, em réplica, procura diferençar as noções de revisão e revisionismo denunciando "as tendências apologéticas da historiografia alemã contemporânea". Segundo o filósofo, contextualizar, comparar e estabelecer vínculos causais não passam de pretexto para "liquidar os danos". Tratar-se-ia de um "neorrevisionismo" associado a um conservadorismo tradicional, cujos pressupostos éticos e políticos implícitos aliviariam o fardo do passado. Nesse sentido, ele denuncia o efeito da desculpação que resulta da dissolução da singularidade dos crimes nazistas..$^{15}$

Com base na argumentação de Habermas, torna-se patente o perigo de se usar o termo revisionismo de maneira descontextualizada, aproximando fenômenos historicamente distintos e singulares. As experiências-limite e os eventos traumáticos são inúmeros no passado e no presente, aspecto que demanda do historiador uma atitude de respeito frente ao sofrimento humano. Transformá-los, pois, em meras funções de uma estrutura universal de massacres conduz à banalização.

\footnotetext{
${ }^{14}$ ARENDT, Hannah. Eichmann em Jerusalém. Um relato sobre a banalidade do mal. Tradução. São Paulo: Companhia das Letras, 2000.

${ }^{15}$ CEZAR, Temístocles. Tempo presente e usos do passado. In: VARELLA, Flávia Florentino, MOLLO, Helena Miranda, PEREIRA, Mateus H. F. e Da MATA, Sérgio (org.). Tempo presente e usos do passado. Rio de Janeiro: Editora FGV, 2012, p. 34.
} 
REVISTA DE HISTÓRIA

SÃO PAULO, N ${ }^{\circ} 169$, p. 255-290,

JULHO / DEZEMBRO 2013
Marco Antonio Silveira

História e política: a historiografia colonial entre a crítica e a responsabilidade (1989-2010)

Essa mesma questão apareceu, no seminário da Ufop, na abordagem do tema da violência. À acusação de que Sidney Chalhoub e Silvia Lara, entre outros, dissolveriam a violência praticada contra o escravo no relativismo e no subjetivismo, a historiadora da Unicamp respondeu acusando Gorender de lidar com ideias estritamente abstratas:

O fato de se afirmar que a escravidão seja uma relação de dominação e exploração violentas (e é claro que ela é), que a sociedade escravista seja uma sociedade desigual (o que é óbvio), não é suficiente para diferenciá-la da sociedade em que vivemos hoje. Nosso mundo também é um mundo de desigualdades (e de desigualdades extremadas); também vivemos relações de dominação e exploração extremamente violentas. Adjetivar a escravidão como violenta, acentuando sobretudo uma ideia de violência absolutamente abstrata, é um procedimento incapaz de diferenciar a escravidão do mundo de hoje. ${ }^{16}$

O raciocínio da autora, além de coadunar-se com a crítica de Habermas, permite que ela exemplifique uma de suas críticas mais fortes a Gorender: a de que sua abordagem seria marcadamente estruturalista: "Não nos preocupamos em saber se os escravos agiam ou não segundo as leis específicas de um bem construído conceito de modo de produção ou qualquer outra modalidade teórica disponível no mercado".17 Nessa colocação, há duas críticas distintas que merecem destaque. A primeira abarca justamente a indicação das insuficiências do estruturalismo, bem como a necessidade de que seja metodologicamente superado através do recurso à reconstituição da historicidade dos fenômenos sociais. A segunda parece apontar para a dinâmica de um mercado historiográfico, no qual se daria a concorrência, inclusive institucional, entre modelos interpretativos distintos. Tal crítica faz lembrar ora dos intensos debates sobre a transição do feudalismo para o capitalismo, ora das discussões sobre a validade do conceito de modo de produção escravista colonial. Mas a referência ao "mercado" também pode ser tomada hoje como um convite para que se compreenda melhor o modo pelo qual a historiografia brasileira se expandiu e se institucionalizou nos últimos vinte anos: como esse mercado se constituiu e quais são suas estratégias de invisibilidade e exclusão? Se os trabalhos de Gorender passaram por forte depreciação, como, por exemplo, as obras de António Manuel Hespanha adquiriram tamanha visibilidade? O que tais oscilações de preço dizem acerca da hierarquização entre universidades, das formas de distribuição dos recursos, das

\footnotetext{
${ }^{16}$ LARA, Silvia. Escravidão no Brasil: um balanço historiográfico, op. cit., p. 225-6.

${ }^{17}$ LARA, Silvia. Escravidão no Brasil: um balanço historiográfico, op. cit., p. 232.
} 
REVISTA DE HISTÓRIA

SÃO PAULO, N 169 , p. 255-290,

JULHO / DEZEMBRO 2013
Marco Antonio Silveira

História e política: a historiografia colonial entre a crítica e a responsabilidade (1989-2010)

táticas de produção de seguidores fiéis, dos modelos de ingresso em cursos de pós-graduação, das práticas de contratação de docentes e das tentativas de inserir-se no mercado historiográfico internacional?

$\mathrm{O}$ argumento atinente à necessidade de se historicizar o conceito de violência, pela relevância que tem, demanda sempre observações. Uma delas tem a ver com a própria lógica do mercado historiográfico, pois a crítica ao anacronismo tornou-se um meio eficaz de descartar interpretações e desqualificá-las como ultrapassadas. Sabe-se como os trabalhos de Hespanha têm contribuído na tarefa de historicizar as categorias que explicam a sociedade colonial. O autor voltou ao assunto em uma obra recente, intitulada Imbecillitas. Não deve surpreender, todavia, que o nono capítulo do livro se chame "Mobilidade", e que, logo no primeiro parágrafo, o historiador esclareça o seguinte ponto: "Não creio ter encontrado nunca, numa fonte histórica da Época Moderna, uma referência a 'mobilidade social'".18 Deveria ser a obra de Hespanha descartada como anacrônica porque, a despeito de todo seu esforço em historicizar as categorias de análise, não pôde escapar a um conceito clássico da Sociologia? A pergunta, claro, é retórica, mas expõe o fato de que todos os historiadores são em alguma medida anacrônicos, e que esse aspecto do ofício não constitui uma peste a ser debelada, mas um elemento metodológico fundamental. Mais ainda, embora o abandono ou a adoção de certos conceitos derivem do esforço dos historiadores de sofisticarem suas análises, a definição de quais anacronismos são aceitos ou rejeitados depende também das relações de força no interior do mercado historiográfico. A noção de família, por exemplo, remete claramente à tensão entre anacronismo e esforço de historicização. As famílias diferiram e diferem grandemente nas várias sociedades, mas ainda se utiliza um mesmo termo para se explorar a diferença e a igualdade existentes entre experiências variadas. Essa suposta universalidade familiar não deve ser entendida como realidade em si, mas como efeito do uso de conceitos - uso sempre problemático. O conceito traz a possibilidade da comparação, aspecto que enriquece a análise historiográfica. Contudo, como se destacou acima, certas comparações - como as indicadas na expressão "historiografia das reabi-

\footnotetext{
${ }^{18}$ HESPANHA, António Manuel. Imbecillitas. As bem-aventuranças da inferioridade nas sociedades de Antigo Regime. São Paulo: AnnaBlume, 2010, p. 251. O autor parte da afirmação citada para sugerir que a ausência de referências à mobilidade na documentação por ele consultada demonstra os limites colocados pela estratificação social no Antigo Regime. Em outras palavras, seu objetivo é justamente o de alcançar um ganho de historicidade. O título do capítulo, contudo, explicita de onde vieram as matrizes teóricas pelas quais é possível colocar o problema.
} 
REVISTA DE HISTÓRIA

SÃO PAULO, N 169 , p. 255-290,

JULHO / DEZEMBRO 2013
Marco Antonio Silveira

História e política: a historiografia colonial entre a crítica e a responsabilidade (1989-2010)

litações" - dissolvem a singularidade e, falando em termos tanto políticos quanto historiográficos, acabam por justificar o injustificável. Assim, a tensão entre comparação e singularidade, entre anacronismo e historicidade, entre estrutura e evento, encontra-se no coração da reflexão historiográfica. Não é possível nem desejável superá-la, mas é fundamental problematizá-la sempre, inclusive colocando-a em relação com a dinâmica da produção, da circulação e do consumo das obras geradas pela historiografia.

Nesse sentido, não constitui necessariamente uma aberração perguntar se a violência do passado escravista continua inscrita na sociedade brasileira. A definição de violência no Aurélio remete a um sentido jurídico, implicando o "constrangimento físico ou moral", o "uso da força", a "coação". Tais significados são amplamente utilizados por pesquisadores diversos. Do ponto de vista teórico, a maioria dos historiadores, afirmando que os conceitos e as categorias não se manifestam como essências, ressaltam também que as estruturas só existem como prática social. Porém, dada a complexidade da operação historiográfica, os estudiosos, sendo sempre obrigados a fazer escolhas, tendem a focar ora a singularidade, ora a repetição resultante, por exemplo, da ocorrência de modelos comportamentais e da dinâmica institucional. Por isso, embora toda história estrutural seja problemática - como é problemático dar aos livros os títulos de História da família, História da vida privada, História econômica, História da escravidão etc. -, o estruturalismo não é seu desdobramento inevitável. Modelos explicativos amplos, que buscam efetuar sínteses globais, serão sempre contestados e modificados em nome do respeito aos fragmentos e à singularidade, mas dificilmente um historiador trabalha sem eles. O problema aparece também, para citar um autor de orientação distinta, nas análises de Jacques Derrida que, partindo de uma forte crítica às visões ontológicas, distingue direito e justiça, identificando o primeiro à regra e à estrutura, e a última à singularidade. Contudo, para o filósofo, o reconhecimento da singularidade da justiça não deve resultar num mergulho que nos exima da luta em torno do direito. ${ }^{19}$ Outra observação acerca do esforço de historicizar o conceito de violência envolve uma possível ambiguidade. Para além dos dilemas concernentes aos usos de conceitos e categorias, há outros três níveis de análise que podem ser distinguidos. O primeiro é a mudança, no decorrer da história, do que é considerado coativo. Se, no passado, era considerado violento não reconhe-

\footnotetext{
${ }^{19}$ DERRIDA, Jacques. Força de lei. Tradução. São Paulo: Martins Fontes, 2007, em especial o capítulo "Do direito à justiça".
} 
REVISTA DE HISTÓRIA

SÃO PAULO, N 169 , p. 255-290,

JULHO / DEZEMBRO 2013
Marco Antonio Silveira

História e política: a historiografia colonial entre a crítica e a responsabilidade (1989-2010)

cer certo atributo capaz de conferir honra a alguém, a violência deixa de fazer sentido se, com o tempo, o dito atributo não é mais concebível como honorável ou se a própria centralidade da honra é deslocada socialmente. $\mathrm{O}$ segundo nível diz respeito não ao entendimento de que este ou aquele ato não é violento, mas, sim, à aceitação da legitimidade de certa violência. Esses dois primeiros níveis apontam para uma distinção fundamental no que concerne à compreensão do castigo exemplar aplicado ao escravo: o fato de um cativo aceitar levar nas costas certo número de chibatadas não significa necessariamente que ele não considere tal ação violenta, mas que considera essa violência legítima. E, nesse ponto, adentra-se a teia complexa da dominação que é, ao mesmo tempo, amarga e doce, física e psíquica. O terceiro nível envia aos limites do conhecimento do historiador: até que ponto a documentação, marcadamente oficial, possibilita a reconstituição da experiência, da memória e das ideias de um escravo? Como comentário geral, dito de passagem, vale dizer que os historiadores talvez acreditem que as colônias americanas constituíam um mundo feito, em última análise, pelos ibéricos simplesmente por desconhecerem de forma cabal as sociedades indígenas e africanas. Retomando, porém, o problema específico da experiência, a alusão ao difícil tema relativo aos testemunhos dos sobreviventes da Shoah ajuda a colocar uma questão metodológica decisiva.

Temístocles Cezar, discutindo as relações impactantes entre, de um lado, o sofrimento físico e psíquico intenso e, de outro, a capacidade ou incapacidade de memória, afirma:

Parece claro, pelo menos para mim, que as técnicas convencionais dos historiadores não são suficientes para a compreensão do Holocausto ou os chamados acontecimentos-limite em regimes policialescos como o de segregação racial na África do Sul ou do terrorismo de Estado das ditaduras latino-americanas do século XX. Com efeito, não seria um exagero afirmar que esse tipo de estudo pode conduzir a reconsiderações das exigências da historiografia em geral.

Logo, essa constatação não deveria ser um impedimento, mas antes um estímulo para a exploração de modos de expressão alternativos que se estendam além da narrativa histórica testemunhal ou acadêmica, como o teatro, a música, o filme e as artes plásticas. ${ }^{20}$

\footnotetext{
${ }^{20}$ CEZAR, Temístocles Cezar. Tempo presente e usos do passado, op. cit, p. 40.
} 
REVISTA DE HISTÓRIA

SÃO PAULO, N ${ }^{\circ} 169$, p. 255-290,

JULHO / DEZEMBRO 2013
Marco Antonio Silveira

História e política: a historiografia colonial entre a crítica e a responsabilidade (1989-2010)

O autor refere-se a acontecimentos-limite ocorridos no último século, perpassados por uma quantidade de testemunhos relativamente ampla. No entanto, a despeito da enorme riqueza desses depoimentos, o trauma a que estão associados desdobra-se em inúmeras aporias relativas ao tratamento da memória e da história. Quando os historiadores se debruçam sobre a sociedade colonial, a dificuldade de reconstituir os sentidos assumidos pela violência física e psíquica fica, por vezes, aquém da constatação de tais aporias - simplesmente porque a documentação é atravessada por um insuportável silêncio. Frente a um sigilo dessa natureza, é importante evitar hipóteses categóricas demais.

Voltando à diferença entre a historicidade do sentido da violência e sua aceitação como algo legítimo, vale retomar as definições de dicionaristas do século XVIII. Rafael Bluteau, na década de 1720, define o verbete "violência" como "força, ímpeto extraordinário", e cita os seguintes exemplos retirados de Cícero: "a violência das doenças", "a violência do frio", "lançar-se a alguém com violência", "violência contra a vontade". O verbete "violentar", por sua vez, é acompanhado da definição "fazer violência", bem como das seguintes citações ciceronianas: "Isto é violentar a gente, porque que importa o modo com que me obrigas a fazer isto? Certamente que me constrangeis"; "Eu fui violentado a fazer isto". No caso de "violento", a definição se refere a "veemente, impetuoso, falando em tormenta, torrente, ira ou outra paixão furiosa". Segue, então, a caracterização de "homem violento, arrebatado, que facilmente se deixa levar da ira"; e ainda a noção de violento como "não natural": "morrer de morte violenta é morrer não de doença ou de velhice, mas de feridas ou outras violências ou desgraças". Antônio de Morais Silva, no final dos Setecentos, retoma, como de costume, as palavras de Bluteau: "violência" é "força, ímpeto", como em "violência da torrente, do vento"; é também "intensidade", a "violência do calor"; e, por fim, "força feita a alguém contra direito". "Violentar" é "fazer força física, constranger, forçar a vontade". E o adjetivo "violento" remete a "veemente, impetuoso, forçoso, que obriga e força", "arrebatado". O violento é também "não natural, por doença", como em "morte violenta", ou ainda o "maltratado contra direito". Por seu turno, o "ímpeto", para Bluteau, é o "impulso que a coisa móvel recebe de causa impelente com força": "movimento violento", "ação impetuosa", "lançar-se a alguém com ímpeto", "ímpeto da natureza". Morais Silva afirma o seguinte: "movimento furioso com grande violência ou impulso"; "o ímpeto das paixões; o abalo grande e a força com que fazer obrar; movido por seus 
REVISTA DE HISTÓRIA

SÃO PAULO, N 169 , p. 255-290,

JULHO / DEZEMBRO 2013
Marco Antonio Silveira

História e política: a historiografia colonial entre a crítica e a responsabilidade (1989-2010)

ímpetos, e não por conselhos de homens nobres". ${ }^{21}$ Ambos os dicionaristas apresentam uma noção de violência que, vinculada em alguma medida ao direito, implica coagir alguém a fazer o que não quer. Nesse sentido, seguindo tal definição, é difícil deixar de concluir que a violência é constitutiva da escravidão. As chamadas negociações entre senhores e cativos em torno da possibilidade de cultivar uma pequena lavoura, de se casar, de ter alguma mobilidade espacial, de não sofrer castigos excessivos, de obter a alforria etc. se dão em meio à correlação de forças. Não ocorre que a violência aconteça aqui e a negociação acolá - ou que a negociação seja o contraponto pacífico da violência. A negociação articula-se à violência constitutiva, disputandose sempre o que, em relação a esta última, é considerado aceitável e legítimo. Isso não significa que tudo fosse violência para um escravo, na medida em que suas relações sociais poderiam ser também atravessadas por formas variadas de solidariedade. Contudo, solidariedade e negociação não consistem na mesma coisa. Ressalve-se, porém, que essa caracterização do cativeiro como constitutivamente violento advém de uma tentativa de historicizar através do recurso a determinados letrados, deixando-se de lado muitos dos sentidos singulares atribuídos à coação por diferentes sociedades africanas ou por quem sofria seus efeitos na carne.

\section{Revisionistas e xiitas}

Por ocasião dos quinhentos anos do descobrimento do Brasil, o debate sobre a escravidão adquiriu coloração nova. Passou-se logo a discutir se fazia sentido comemorar um evento que desembocou na constituição de uma sociedade escravista, geradora de desigualdades e estratégias racistas presentes na passagem para o século XXI. O fantasma do revisionismo ou da reabilitação continuava a rondar os meios universitários. Em sua crítica, Jacob Gorender havia estabelecido conexões diretas entre a postura dos historiadores e certas datas comemorativas tais como os 200 anos da Revolução Francesa e os 500 anos da descoberta da América. Estariam os acadêmicos ajudando a erguer monumentos à iniquidade? Foi nesse contexto que Laura de Mello e Souza concedeu uma entrevista à Folha de S. Paulo, na qual a primeira pergunta era justamente se havia algo a comemorar. A resposta da historiadora foi a seguinte:

\footnotetext{
${ }^{21}$ BLUTEAU, Rafael. Vocabulário português e latino. Coimbra: Colégio das Artes da Companhia de Jesus, 1712-1728. SILVA, Antônio de Morais. Dicionário da língua portuguesa. Lisboa: Tipografia Lacerdina, 1789.
} 
REVISTA DE HISTÓRIA

SÃO PAULO, N ${ }^{\circ} 169$, p. 255-290,

JULHO / DEZEMBRO 2013
Marco Antonio Silveira

História e política: a historiografia colonial entre a crítica e a responsabilidade (1989-2010)

Há aspectos importantes a comemorar, mas também um legado horrível, que é formado por tudo o que não fizemos e que nos deixa angustiados. Passados 500 anos, ainda mantemos uma estrutura iníqua, que tem a ver com a forma como se processou a colonização. Mas não é só isso. Somos responsáveis pelos nossos atos. De fato, é um preço muito alto que se pagou pela escravidão. Mas faz mais de cem anos que ela foi abolida e ainda não conseguimos resolver a questão da desigualdade. ${ }^{22}$

As palavras de Laura de Mello e Souza conjugavam três elementos diferentes: a existência de um legado positivo, isto é, os "aspectos importantes a comemorar"; a ocorrência de um legado negativo, ou seja, o preço alto pago pela escravidão; e a necessidade de se responsabilizar pela "estrutura iníqua" herdada. O segundo elemento indicado reaparece em diversos momentos do restante da entrevista. A historiadora mencionou a "intolerância" já vigente no Império português e adiante arrematou: "O que mais me assusta, porém, é que a sociedade brasileira seja uma sociedade violenta, de uma violência que nem sempre é aparente". ${ }^{23}$ Enfrentando o terceiro ponto, atinente à responsabilização, mostrou-se incisiva diante da pergunta sobre se "a tensão entre barbárie e civilização é um fardo que o Brasil carrega":

Sim, sobretudo porque em grande parte as elites assumiram esse caráter. A vertigem do Brasil é que a barbárie pode engolir a civilização. A ideia de que o sertão vai virar mar e o mar vai virar sertão é sempre posta, recriada pelas elites que negam suas origens. Poucos países têm uma elite tão predadora como a brasileira. Não adianta dizer que são os outros. A elite somos nós. E vamos entrar no século 21 com essa questão em aberto. ${ }^{24}$

A asserção trazia à tona um problema absolutamente decisivo: boa parte dos professores universitários e acadêmicos constitui uma elite cultural que, além de impactar pelas formas de circulação das ideias, recorrentemente compõe o grupo político dirigente - seja através da ocupação de postos nas próprias universidades ou nos órgãos estatais de financiamento, seja por meio da ascensão ao primeiro escalão dos governos. Crítica à iniquidade herdada e responsabilização diante dela - eis dois elementos cruciais conjugados na entrevista.

\footnotetext{
${ }^{22}$ Intolerância é legado colonial, afirma Laura de Mello e Souza. Folha de S. Paulo, 20 de março de 2000, Caderno Brasil, p. 9.

${ }^{23}$ Intolerância é legado colonial, afirma Laura de Mello e Souza. Folha de S. Paulo, 20 de março de 2000, Caderno Brasil, p. 9.

${ }^{24}$ Intolerância é legado colonial, afirma Laura de Mello e Souza. Folha de S. Paulo, 20 de março de 2000, Caderno Brasil, p. 9.
} 
REVISTA DE HISTÓRIA

SÃO PAULO, N 169 , p. 255-290,

JULHO / DEZEMBRO 2013
Marco Antonio Silveira

História e política: a historiografia colonial entre a crítica e a responsabilidade (1989-2010)

Contudo, a avaliação acerca do primeiro ponto - os aspectos a serem comemorados -, titubeia em alguns momentos. A entrevistada, indicando uma vantagem do Brasil em relação a países como a França, destaca o "pluriculturalismo" como "um cacife importante para entrar no século 21" - referência à possibilidade de o país se constituir como uma sociedade efetivamente democrática e plural. E acrescenta de imediato: “O Brasil, porém, não é uma democracia racial. É um país desigual. Mas somos um país mestiço, e isso é importante. Mestiçagem não só étnica, mas cultural". ${ }^{25}$ Mais à frente, afirma que o Império luso foi "feito de tolerância e intolerância". E completa: "O Brasil não é apenas uma democracia racial, como dizia Gilberto Freyre, mas um país que discrimina o tempo todo". ${ }^{26}$ Nesse último trecho, o advérbio provoca algum incômodo. Haveria alguma dimensão de democracia racial no Brasil? A ambiguidade resultante da palavra apenas contrasta claramente com o teor geral da entrevista, na qual, como se viu, a mesma frase sobre o pensamento de Gilberto Freyre é dita sem advérbio algum. A questão central consiste em avaliar o que a historiadora buscava ao escorregar na ambiguidade.

O debate acerca da escravidão iniciado na década de 1980 - e que culminou com as tensões que apareceram no seminário ufopiano - trazia em seu bojo uma crítica à chamada "escola paulista" que, ao buscar desqualificar a ideia de democracia racial e a apropriação salazarista de Gilberto Freyre, tendeu em parte a tratar o escravismo nos termos da reificação, reproduzindo, inclusive, determinados preconceitos expressos pelos viajantes europeus do Brasil oitocentista. Uma das consequências positivas desse debate consistiu, pois, na retomada das reflexões freyrianas, ainda que não de maneira ingênua. As noções de "pluriculturalismo" e de "mestiçagem" referidas por Laura de Mello e Souza, porém, ficam soltas no ar - o que, evidentemente, é também o resultado das condições inerentes a uma entrevista desse tipo. A maneira como a historiadora encerra a entrevista indica novamente a sensação de deslocamento desses termos quando inseridos no quadro mais geral da reflexão:

Acho que a gente não enfrenta as coisas, tanto para o bem quanto para o mal. No mundo hispânico, me parece que os embates são muito mais abertos, enquanto, no

\footnotetext{
${ }^{25}$ Intolerância é legado colonial, afirma Laura de Mello e Souza. Folha de S. Paulo, 20 de março de 2000, Caderno Brasil, p. 9.

${ }^{26}$ Intolerância é legado colonial, afirma Laura de Mello e Souza. Folha de S. Paulo, 20 de março de 2000, Caderno Brasil, p. 9. Grifo meu.
} 
REVISTA DE HISTÓRIA

SÃO PAULO, N ${ }^{\circ} 169$, p. 255-290,

JULHO / DEZEMBRO 2013
Marco Antonio Silveira

História e política: a historiografia colonial entre a crítica e a responsabilidade (1989-2010)

mundo lusitano, são sempre meio "na maciota". Há uma dificuldade de enfrentamento que é típica dessa cultura. Temos essa tradição de coisas não ditas, de meios-tons. ${ }^{27}$

A hipótese de que a sociedade brasileira tem evitado, no decorrer de sua história, os enfrentamentos, privilegiando conciliações e mudanças graduais, tornou-se recorrente entre os intelectuais e remete, por exemplo, à imagem do "homem cordial" de Sérgio Buarque de Holanda. Percebe-se, na entrevista de Laura de Mello e Souza, o impacto da leitura dos clássicos e de suas contribuições. Contudo, por que a historiadora teria feito questão de frisar esse ponto? A expressão na maciota é definida no Aurélio nos seguintes termos: "sem esforço; sem se alterar; calmamente"; "sem complicações ou dificuldades; em paz; serenamente". É sugestivo relacionar tais observações não apenas aos dilemas experimentados pela historiografia após a crise aberta pela crítica ao marxismo, mas também com o quadro de desmobilização gerado no governo FHC. Laura de Mello e Souza, assim como o fizera Silvia Lara quase uma década antes, destacou a importância do enfrentamento político, mas a mensagem do pluriculturalismo indicava alguma incerteza. Conquanto o uso do termo se referisse à importância de se reconhecer a legitimidade dos direitos de grupos sociais marginalizados e alvos de preconceito, visando a constituição de uma sociedade efetivamente democrática, restava a ambiguidade derivada da longa tradição calcada na ideia de mestiçagem.

Seja como for, retomando o que foi dito acima, a entrevista articulava crítica à iniquidade, responsabilização e demanda pelo enfrentamento. Alguns anos depois, em 2006 - momento em que a reforma gradual do lulismo começava a dizer claramente a que viera -, a Folha de S. Paulo foi palco de outra entrevista interessante. Irritado com as críticas que seus trabalhos vinham recebendo, o historiador João Fragoso desabafou:

Mais radicais que o [Fernando] Novais são seus seguidores atuais, que eu chamo de xiitas. Que querem sublinhar alguma coisa que nos anos 60 já havia sido descartada, as teorias da dependência, no sentido amplo. Aqui e talvez a Venezuela são os únicos lugares no mundo em que ainda se leva a sério isso. Você tem aí um ranço que é da Guerra Fria.

Isso é uma coisa. A outra é que ainda se acredita que as pessoas são criaturas de um modo de produção - ou das estruturas. Você tem o capitalismo, e as pessoas se comportam conforme essa estrutura. Ele é gestado, consequentemente as pessoas têm que

\footnotetext{
${ }^{27}$ Intolerância é legado colonial, afirma Laura de Mello e Souza, Folha de S. Paulo, op. cit., p. 9.
} 
REVISTA DE HISTÓRIA

SÃO PAULO, N 169 , p. 255-290,

JULHO / DEZEMBRO 2013
Marco Antonio Silveira

História e política: a historiografia colonial entre a crítica e a responsabilidade (1989-2010)

ter um comportamento pertinente àquilo que o capitalismo algum dia será. As pessoas são tratadas como marionetes.

Com isso, obviamente, não estou descaracterizando a existência de um reino, de um centro de poder. Mas você tem negociações. Você tem tensão.

Se você entende anacronismo desse modo, como a teimosia da teoria da dependência e das estruturas, aí sim. ${ }^{28}$

As palavras de Fragoso remetiam a um sem-número de problemas historiográficos acumulados. Antes de tudo, correspondiam a mais um capítulo do debate sobre a herança marxista no Brasil. Dessa vez, no entanto, aparecia com clareza um corte ao mesmo tempo político e temporal: o antes e o depois da Guerra Fria. A menção à Venezuela era provocativa e buscava associar a "teimosia da teoria da dependência" à figura de Hugo Chávez. Haveria um pensamento ultrapassado e um novo, mais adequado às condições históricas surgidas depois da queda do Muro de Berlim - contraponto que recorria ao "anacronismo" como estratégia de deslocamento. Ademais, reaparecia a crítica também formulada por Silvia Lara uma década e meia antes: a visão estruturalista transformava as pessoas em marionetes. Porém, enquanto Silvia Lara, embora também questionasse a chamada "escola paulista", havia visado mais categoricamente Jacob Gorender, no comentário de Fragoso não parecia haver muitas gradações - diga-se novamente que problemas desse tipo podem resultar das condições de produção de uma entrevista. Outro ponto instigante era a observação de que Fragoso não descaracterizava “a existência de um reino, de um centro de poder" - o que chama a atenção quando se pensa em sua apropriação do pensamento de Hespanha. Ressurgia, como não podia deixar de ser, o termo negociação.

Ainda que as críticas de João Fragoso produzissem certo efeito caricatural na descrição do debate, sua irritação talvez fosse justificada: "A coisa que mais escuto é me compararem com alguma literatura salazarista". E continuava:

O grande império português, aquela coisa do Salazar. Nos acusam de estarmos eliminando toda e qualquer contradição. Não levaríamos em conta duas contradições

\footnotetext{
${ }^{28}$ A culpa é nossa. Folha de S. Paulo, 13 de fevereiro de 2006, Ilustrada, p. E1.
} 
REVISTA DE HISTÓRIA

SÃO PAULO, N ${ }^{\circ} 169$, p. 255-290,

JULHO / DEZEMBRO 2013
Marco Antonio Silveira

História e política: a historiografia colonial entre a crítica e a responsabilidade (1989-2010)

fundamentais: colônia x metrópole e senhores x escravos. É o discurso marxista - olha, sou marxista, mas para tudo há limites. ${ }^{29}$

Talvez a referência à acusação de salazarismo resultasse de estratégia retórica através da qual a virulência da crítica aparece justificada pela atribuição do vitupério ao oponente. Mas se ela de fato ocorreu, foi injusta e ofensiva. Ademais, como se sugeriu acima acerca das livres associações de Gorender, não se devem esvaziar os crimes de Salazar. Entretanto, chama também a atenção o uso da palavra xiita, ou, em outra formulação contida na entrevista, geração de xiitas. É possível questionar se determinados historiadores brasileiros merecem ser chamados de xiitas. Mas seriam os xiitas merecedores de serem comparados com os historiadores brasileiros? Se a pergunta parece um non sense, isso ocorre simplesmente porque parte expressiva dos intelectuais do Brasil nada conhece a respeito do Islã. Enfim, a metáfora utilizada por Fragoso, ao associar os xiitas à irracionalidade e ao fanatismo, foi certamente etnocêntrica. Pouco adianta, contudo, fulanizar essa constatação, uma vez que tal metáfora, com toda sua conotação negativa, circula amplamente no ambiente acadêmico brasileiro.

Pode-se argumentar que uma observação dessa espécie vincula-se às formas mais lamentáveis do politicamente correto. E seria preciso levar o argumento a sério, pois o referido movimento desdobrou-se comumente em estratégias de controle e disciplina da fala cotidiana, capazes de produzir meios de internalização da censura. Todavia, é importante lembrar que a crítica ao politicamente correto intensificou-se no final da década de 1990, nos Estados Unidos, a partir da multiplicação de meios de difusão patrocinados ou estimulados pelo Partido Republicano e por instituições ligadas a suas propostas. Baseando-se na tese de que as universidades estariam passando por um perigoso declínio e de que nelas se incentivaria o racismo invertido, os conservadores norte-americanos visavam atingir justamente o pluriculturalismo - entendido como a abertura para grupos sociais discriminados, inclusive negros -, bem como promover o ensino superior privado, sob o argumento de que diminuir impostos levaria os cidadãos, de posse de mais recursos, a escolherem livremente onde desejavam de fato estudar. ${ }^{30}$ A recordação desse

\footnotetext{
${ }^{29}$ A culpa é nossa. Folha de S. Paulo, 13 de fevereiro de 2006, Ilustrada, p. E1.

${ }^{30}$ Cf. MESSER-DAVIDOW, Ellen. Manufacturing the attack on liberalized higher education. Social Text, n. 36, outono de 1993, p. 40-80. Segundo a autora, "O ataque ao multiculturalismo tem sido bastante amplo porque a abertura do currículo a raças e culturas até então excluídas enquadra com outros esforços na academia e na sociedade aos quais os conservadores se
} 
REVISTA DE HISTÓRIA

SÃO PAULO, N 169 , p. 255-290,

JULHO / DEZEMBRO 2013
Marco Antonio Silveira

História e política: a historiografia colonial entre a crítica e a responsabilidade (1989-2010)

aspecto do problema não tem o objetivo de propor que João Fragoso é etnocêntrico, preconceituoso ou conservador ao estilo do Partido Republicano. O fundamental consiste em ressaltar que tratar o debate historiográfico como uma disputa entre revisionistas e xiitas não contribui para a compreensão das questões cruciais. Mais interessante é o caminho aberto pela afirmação categórica de Laura de Mello e Souza, provavelmente compartilhada por Fragoso: "A elite somos nós". Qual a relação entre a posição social dessa elite e seus discursos historiográficos? Em que medida, a despeito de todos os esforços críticos, a elite intelectual - seja ela qual for, esteja onde estiver, trabalhe onde trabalhar - reproduz preconceitos e posições conservadoras?

O tema da responsabilização aparece também na entrevista de Fragoso. O historiador ressalta que uma sociedade injusta e desigual, no passado ou no presente, não se sustentaria se os grupos dominados não conferissem alguma legitimidade às formas de dominação. Dessa forma, afirma:

Repetindo a frase de minha velha professora Maria Yedda Linhares, ainda na Guerra Fria: "O Brasil se tornou independente em 1822. Depois disso, é falta de vergonha". Estendendo um pouquinho para trás... Ou seja, o destino é nosso. É a sociedade com todos os seus grupos, sem livrar a cara de ninguém. O mais pobre dos pobres, o mais operário dos operários. Os mais humildes compartilham dessa abstração chamada sociedade brasileira. Com todas as suas contradições e desigualdade de renda. Não estou dizendo que todo mundo cante a mesma música, mas sim que algumas coisas básicas, em algum grau, são compartilhadas. Porque senão essa bodega não funcionava. ${ }^{31}$

Nessa passagem, a menção a Maria Yedda Linhares é associada à depreciação do pensamento dos supostos oponentes através de nova referência à Guerra Fria. A repetição dessa tópica - a de "teimosia" ou atraso de certas concepções frente às mudanças ocorridas na história - faz pensar sobre o impacto do discurso relativo à "nova ordem mundial" nas reflexões historiográficas. O argumento parece ser o de que, num passado caracterizado pela polarização entre Estados Unidos e União Soviética, era compreensível levar a sério análises focadas na oposição entre países desenvolvidos e sub-

opõem: por exemplo, o ativismo afro-americano e gay, a ação afirmativa e os códigos de fala intolerante. Durante os últimos quatro anos, eles publicaram dúzias de artigos críticos ao multiculturalismo, ao afrocentrismo e ao suposto racismo invertido em Commentary, National Review, New Republic e outros periódicos. A maioria traz títulos provocativos que ridicularizam esses projetos [...] ou que apropriam a retórica antirracista com o intuito de colocar a opinião pública contra projetos antirracistas" (p. 42). Tradução minha.

31 A culpa é nossa. Folha de S. Paulo, op. cit. 
REVISTA DE HISTÓRIA

SÃO PAULO, N ${ }^{\circ} 169$, p. 255-290,

JULHO / DEZEMBRO 2013
Marco Antonio Silveira

História e política: a historiografia colonial entre a crítica e a responsabilidade (1989-2010)

desenvolvidos - as alterações no capitalismo e na geopolítica internacional, no entanto, teriam demonstrado a falência de ideias dessa espécie. Seria, nesse caso, preciso provar que a teoria da dependência havia desmoronado completamente após a queda do Muro de Berlim. Essa não era a opinião de Fernando Henrique Cardoso que, em entrevista de 2010, rechaçando a afirmação de que teria dito conhecida e foclórica frase, e comentando o título do livro que acabara de lançar, Relembrando o que escrevi, disse:

Fiz questão até do título, porque inventaram o "esqueçam tudo o que escrevi". Chega de dizer bobagens. O que não quer dizer que não tenha evoluído no meu pensamento, mudado aqui e ali. Mas nunca disse isso, pelo contrário. Aliás, lembrem, por favor. A maior parte das pessoas que afirma isso nunca leu o que escrevi no passado. E às vezes pegam o presente e pensam que estou mudando de opinião, porque não leram o que disse antes. Teriam de ter acompanhado a evolução. ${ }^{32}$

Outro ponto se destaca na referida passagem de Fragoso, aparecendo inclusive acompanhada de reticências: "Estendendo um pouquinho para trás...". A colocação de Maria Yedda Linhares, segundo a citação feita por João Fragoso, dizia respeito ao Brasil propriamente dito, surgido após 1822, dado que, a princípio, levaria à distinção entre a situação colonial e a independente. Estender um pouquinho para trás não consiste numa operação simples, pois o problema da responsabilização não pode ser equacionado da mesma maneira nos dois contextos - a diferença entre um e outro é justamente a presença do colonizador. Se, seguindo o raciocínio proposto por Fragoso, a responsabilidade pelo destino do Brasil, ou a "falta de vergonha", inicia-se antes da independência, seria decisivo circunscrever em que consiste, então, a responsabilidade do colonizador. ${ }^{33}$ Mais ainda, embora Fragoso acentue

\footnotetext{
${ }^{32}$ CARDOSO, Fernando Henrique e HERZ, Pedro. Revista da Cultura, abril de 2010. (Não há texto. Trata-se de uma entrevista concedida por FHC a Pedro Herz na Revista da Cultura. O nome da entrevista é "Fernando Henrique Cardoso e Pedro Herz".) Acessado em www.revistadacultura. com.br:8090/revista/rc33/index2.asp?page=entrevista. Em texto de 1997, um oponente de Fernando Henrique, o futuro ministro Guido Mantega, também apresentou uma interpretação bastante positiva e diversificada das teorias da dependência, evitando tratá-las, para usar a expressão de Fragoso, "no sentido amplo". Cf. MANTEGA, Guido. Teoria da dependência revisitada - um balanço crítico. São Paulo: Fundação Getúlio Vargas. Escola de Administração de Empresas de São Paulo. Centro de Estudos. Núcleo de Pesquisa e Publicações, 1997. (Relatório de Pesquisa $n^{\circ}$ 27). Acessado em bibliotecadigital.fgv.br/dspace/handle/10438/3003?show=full.

33 Vale mencionar que uma formulação dessa natureza, isto é, relativa à responsabilidade do colonizador, tem aparecido atualmente em debates sobre a quem cabe pagar o maior preço nas estratégias de redução das emissões que geram o aquecimento global. Em outras palavras,
} 
REVISTA DE HISTÓRIA

SÃO PAULO, N 169 , p. 255-290,

JULHO / DEZEMBRO 2013
Marco Antonio Silveira

História e política: a historiografia colonial entre a crítica e a responsabilidade (1989-2010)

que nem todos cantem a mesma música, não deixa de ser também perturbadora a assertiva de que não se deve "livrar a cara de ninguém". Afirmar que uma sociedade tem de ser "compartilhada por todos os grupos sociais", como assevera um pouco antes do trecho citado acima, não é dizer muita coisa. O fundamental é demonstrar - algo, diga-se logo, bastante difícil numa curta entrevista - como cada grupo se posiciona na sociedade, o que compartilha, o que deixa de compartilhar, por que e em que condições.

A referência a uma situação histórica deveras distinta daquela tratada por Fragoso aponta para a complexidade da questão. Na história da expansão nazista, é constantemente retomado o tema da colaboração, efetuada seja pelos próprios alemães fascinados com a simbologia e a gestualidade de Adolf Hitler, pelas autoridades de Vichy ou por membros da própria comunidade judaica. Quando se discute a iniquidade dos campos de concentração, aparece a dúvida sobre o porquê de não ter havido rebeliões intensas e em grande número, bem como a incompreensão relativa à passividade quase total de alguns prisioneiros. No que concerne a esse último ponto, uma resposta às dúvidas levantadas indica a capacidade de certos meios coercitivos de liquidarem física e psiquicamente as pessoas. O exemplo é aqui evocado não para se deixar no ar qualquer possibilidade de associação entre as reflexões de Fragoso e os chamados revisionistas. Como se disse acima acerca da noção de "historiografia das reabilitações", associações desse tipo são inadequadas - desqualificam historiadores e banalizam a crueldade da Shoah. Além disso, embora a escravidão fosse constitutivamente violenta e tenha sido vivida como acontecimento-limite, não pode ser identificada com a atuação de uma máquina de guerra e extermínio cuja sofisticada tecnologia tornava-a capaz de produzir massacres até então inimagináveis. Apesar dessas ressalvas, porém, o exemplo nazista auxilia no entendimento de que há formas bastante distintas de "compartilhar" a sociedade, a responsabilização de cada um devendo ser avaliada, portanto, com cuidado. É indispensável tentar superar concepções dicotômicas que vitimizem determinados indivíduos ou grupos sociais, ignorando, por exemplo, a força do ressentimento como tática de poder. ${ }^{35} \mathrm{~A}$ incorporação de tais abordagens, todavia, não conduz à

puxar um pouquinho para trás a discussão tem implicações políticas bastante concretas no cenário internacional do século XXI.

${ }^{34}$ FRAGOSO, op. cit..

${ }^{35} \mathrm{O}$ tema é formulado por Maria Rita Kehl, que procura definir o ressentimento valendo-se tanto das análises freudianas sobre o luto e a melancolia, quanto do pensamento de Nietzsche. KEHL, Maria Rita. Ressentimento. $4^{\mathrm{a}}$ ed. São Paulo: Casa do Psicólogo, 2011. Numa perspectiva 
REVISTA DE HISTÓRIA

SÃO PAULO, N ${ }^{\circ} 169$, p. 255-290,

JULHO / DEZEMBRO 2013
Marco Antonio Silveira

História e política: a historiografia colonial entre a crítica e a responsabilidade (1989-2010)

ideia de que não existem vítimas. A posição de um escravo que ocupa lugar privilegiado na milícia privada de seu senhor é diferente daquela vivenciada por um cativo perseguido sadicamente a ponto de morrer em decorrência das feridas abertas causadas pelo excesso de castigo. Essas observações podem parecer óbvias, mas é importante retomá-las com o intuito de destacar que não livrar a cara de ninguém sem qualificar devidamente a questão - esclarecendo qual é a música cantada por cada um - consiste, no fundo, em dizer que ninguém pode ser pontualmente responsabilizado por nada.

Por fim, o trecho citado traz uma surpreendente colocação, atinente à necessidade de se compreender como a dominação era legitimada por diferentes grupos sociais: "Porque senão essa bodega não funcionava". Segundo o Aurélio, bodega significa "taberna", "pequeno armazém de secos e molhados", "comida grosseira e malfeita", "coisa suja", "porcaria", "imundície", "coisa insignificante, reles ou imprestável". Como interjeição, "exprime descontentamento, irritação". Deve-se retomar a crítica à censura do politicamente correto. Deve-se ainda lembrar que, assim como os significados atribuídos por Bluteau e Morais Silva não podem ser reificados nas análises sobre a sociedade colonial setecentista, também é preciso ter cuidado com o uso do Aurélio como instrumento de interpretação de uma entrevista dada em condições específicas. Essas ressalvas são importantes. Acrescente-se a elas que, como ocorre com o uso pejorativo do termo xiita, a expressão aludida é amplamente utilizada na sociedade brasileira, inclusive nos meios universitários. Num certo sentido e isso depende da música que cada um toca -, as palavras de Fragoso são as palavras de todos nós. Por isso mesmo vale a pena formular duas questões. A primeira: o recurso à metáfora da bodega na caracterização da sociedade colonial ou da sociedade brasileira indica a partilha, nos meios acadêmicos, de preconceitos a respeito do país? A segunda: na frase citada, o enunciador se coloca como proprietário, frequentador ou empregado da bodega?

distinta, Adriana Romeiro busca resgatar o papel do ressentimento nas estratégias de ascensão social baseadas na requisição de mercês na América portuguesa. ROMEIRO, Adriana. Honra e ressentimento - a trajetória de Garcia Rodrigues Pais em busca das mercês régias. In: ANTUNES, Álvaro de Araújo e SILVEIRA, Marco Antonio (org.). Dimensões do poder em Minas (séculos XVIII e XIX). Belo Horizonte: Fino Traço, 2012, p. 11-47. 
REVISTA DE HISTÓRIA

SÃO PAULO, N 169 , p. 255-290,

JULHO / DEZEMBRO 2013
Marco Antonio Silveira

História e política: a historiografia colonial entre a crítica e a responsabilidade (1989-2010)

\section{Bodega e universidade}

Uma das formas de seguir a pista lançada pela frase de João Fragoso implica em pensar como os intelectuais, e em especial os acadêmicos do campo da história, contribuem para a bodega funcionar. Sabe-se que uma das classificações mais utilizadas para medir indicadores sociais é a que divide a população em quatro categorias de renda: até dois salários mínimos, de dois a cinco, de cinco a dez, e mais de dez. Embora esse modelo classificatório mascare diferenças cruciais no interior de cada grupo, dele se conclui que parte dos professores universitários compõe a elite econômica. Os historiadores não são ricos como banqueiros, especuladores e alguns executivos, mas, num país caracterizado por tamanha desigualdade, não deixam de compor a base de uma camada economicamente privilegiada. Entre os próprios historiadores, no entanto, há diferenças significativas. Uma razão para não generalizar é o fato de que, nas últimas décadas, as políticas governamentais trouxeram mudanças no funcionamento das universidades públicas e diversificaram as instituições de ensino superior, ampliando o espaço ocupado pelos grupos privados, nos quais as condições de trabalho às vezes ficam bem abaixo do razoável. ${ }^{36} J a ́$ na presidência de Fernando Henrique Cardoso, a crítica às universidades federais - baseada na ideia de que o tripé ensino/ pesquisa/extensão não atendia às necessidades do mercado - vinculou-se a concepções oriundas do Banco Mundial, das quais resultou a criação de cursos de curta duração e à distância. Embora a aprovação da Lei de Diretrizes e Bases da Educação Nacional (LDB), em 1996, conjugasse o incentivo ao ensino privado com a manutenção do papel das instituições públicas, efetivou-se uma clara política de sucateamento das universidades federais através da diminuição do financiamento, da redução de salários e da perda de professores e funcionários técnico-administrativos - prejuízos que não impediram, contudo, o aumento de vagas e a criação de cursos noturnos. Um dos resultados desse fenômeno consistiu na captação de recursos por meio da oferta de cursos pagos de extensão e de parcerias com fundações privadas - não

\footnotetext{
${ }^{36}$ O parágrafo que segue vale-se amplamente da síntese elaborada por Cristina Helena Almeida de Carvalho, embora a autora não seja responsável por qualquer interpretação ou acréscimo de observações. Cf. CARVALHO, Cristina Helena Almeida de. Política para o ensino superior do Brasil (1995-2006): ruptura e continuidade nas relações entre público e privado. 29a REUNIÃO DA ASSOCIAÇÃO NACIONAL DE PÓS-GRADUAÇÃO E PESQUISA EM EDUCAÇÃO. GT Política de Educação Superior. Anais. 2006. Acessado em www.anped.org/reunioes/29ra/ trabalho/GT11-2337--Int.pdf.
} 
REVISTA DE HISTÓRIA

SÃO PAULO, N 169 , p. 255-290,

JULHO / DEZEMBRO 2013
Marco Antonio Silveira

História e política: a historiografia colonial entre a crítica e a responsabilidade (1989-2010)

surpreendendo a ocorrência recente de denúncias de corrupção envolvendo algumas delas. A criação da categoria de instituições de ensino sem fins lucrativos constituiu mais um fator cujo resultado foi o aumento acelerado de vagas em empresas privadas, embora a procura não tenha se revelado tão frutífera. Em 2003, o governo Lula, atento aos interesses das empresas ligadas à educação, estabeleceu como prioridade não a expansão de matrículas e cursos, mas a sustentação do modelo privado já existente. Daí a criação do Programa Universidade para Todos (ProUni), desenvolvido num contexto de preocupação dos empresários com o número de vagas ociosas. Uma vez que o programa se apresentava como visando à justiça social, foi também apoiado por setores da sociedade civil e pela CUT. Sua aplicação, porém, não tem garantido amplamente a permanência dos alunos nos cursos ou a conclusão destes. Por outro lado, em contraste com as orientações do Banco Mundial, a administração petista não deixou de adotar a fiscalização do ensino privado - ainda que ela ocorra de modo sempre limitado -, estimulando ainda a expansão das instituições públicas. Foram erguidas novas universidades federais e novos campi - que têm funcionado muitas vezes sem as condições devidas -, contratados, até 2006, cerca de quatro mil docentes e encaminhadas em parte as perdas salariais. A despeito da ambiguidade típica do lulismo, sua política em relação às universidades federais parece ter contribuído para a manutenção do prestígio do presidente e de seu partido nos meios acadêmicos, num quadro marcado pelo abandono de muitas de suas antigas bandeiras e pela adoção das antigas práticas partidárias.

As oscilações nas políticas concernentes ao ensino superior foram acompanhadas da indiscutível profissionalização da disciplina História, tanto no sentido de sua expansão e organização institucional, quanto no que diz respeito ao reconhecimento legal do exercício do ofício. Essa profissionalização tem devido muito à multiplicação de cursos de pós-graduação por todo o país, cuja avaliação é feita pela Coordenação de Aperfeiçoamento de Pessoal de Nível Superior (Capes), através da atribuição de conceitos derivados, em boa medida, da análise de relatórios trienais. Sem descurar de seus aspectos positivos - atinentes, por exemplo, à inserção de um número maior de estudantes em cursos de mestrado e doutorado -, ressalte-se que o modelo de profissionalização em voga tem gerado, pelo menos, dois problemas capitais. O primeiro implica certa fragmentação do debate historiográfico - fenômeno que, de resto, envolve amplos setores da sociedade brasileira devido à proliferação de dados produzidos pelas novas tecnologias. Tal fragmentação manifesta-se através da dificuldade cada vez maior de se acompanhar a produção historiográfica, o que redunda em tendência de intensa especialização 
REVISTA DE HISTÓRIA

SÃO PAULO, N 169 , p. 255-290,

JULHO / DEZEMBRO 2013
Marco Antonio Silveira

História e política: a historiografia colonial entre a crítica e a responsabilidade (1989-2010)

e na diminuição da capacidade de pensar questões mais gerais. Manifesta-se também pela multiplicação de eventos e de meios de divulgação situados nas mais variadas partes do Brasil, aspecto que, embora positivo por integrar determinadas regiões e estimular sua historiografia, resulta paradoxalmente em limites à constituição de espaços públicos aptos a articular o debate.

Em certa medida, os mecanismos de fragmentação têm sido conjugados com a hegemonia ainda mantida pelas universidades maiores ou mais prestigiadas localizadas no eixo que abarca o Rio de Janeiro e São Paulo. É interessante perguntar, inclusive, se a polarização entre "escola paulista" e "escola carioca" - para referir expressões que têm sintomaticamente aparecido em inúmeras dissertações e teses, infelizmente sem a devida reflexão - não constitui, paradoxalmente, um sinal de turbulência numa hegemonia talvez em crise. Se o debate entre tais "escolas" se esgotasse - como ocorreu com as disputas acerca da validade do conceito de modo de produção escravista na década de 1980 -, a historiografia colonial poderia momentaneamente perder-se entre especializações temáticas e espaciais. Permanece comum, em meio à variedade de eventos, a estratégia que elege um número relativamente restrito de convidados para conferências e mesas-redondas, já que, sendo eles considerados os historiadores que têm efetivamente algo a dizer, levam consigo o prestígio necessário ao sucesso dos empreendimentos locais. Uma estratégia semelhante, embora envolvendo um grupo bem mais amplo, é adotada nos convites para a participação em bancas de pós-graduação. Os pesquisadores brasileiros podem discutir à exaustão se a monarquia corporativa contradiz a noção de sistema colonial, mas, no que concerne ao mercado historiográfico, continua a haver centro e periferia - e, embora as universidades localizadas em cidades menos pujantes possam acumular internamente algum capital, permanecem dependendo dos recursos humanos vindos das regiões hegemônicas para alcançar desenvolvimento. ${ }^{37} \mathrm{O}$ segundo problema derivado do atual modelo de profissionalização abarca o polêmico tema do produtivismo. É cada vez mais recorrente encontrar nas universidades públicas docentes que repetem com frequência estarem esgotados. As exigências advindas da tarefa de ministrar aulas, da orientação de

\footnotetext{
37 Destaque-se, no entanto, que a própria política das agências de fomento tem visado distribuir recursos de maneira a reconhecer e incentivar profissionais de diversas regiões do Brasil. Destaquese, ainda, quanto aos historiadores considerados como aqueles que têm algo a dizer, que, embora seu prestígio possa eventualmente advir apenas do lugar institucional que ocupam, a maioria tem sido reconhecida por seus méritos e pela autoridade intelectual que alcançaram com justiça.
} 
REVISTA DE HISTÓRIA

SÃO PAULO, N ${ }^{\circ} 169$, p. 255-290,

JULHO / DEZEMBRO 2013
Marco Antonio Silveira

História e política: a historiografia colonial entre a crítica e a responsabilidade (1989-2010)

alunos de graduação e pós-graduação, da participação em eventos, da escrita de livros e artigos, e do empenho em atividades de gestão aumentam a cada dia. Elas resultam de razões variadas que vão desde a falta de funcionários técnico-administrativos até a necessidade de alimentar os dados do Coleta (o formulário de avaliação dos cursos de pós-graduação da Capes), passando pela obsessão individual com o sucesso na carreira - traço psíquico que faz qualquer bodega funcionar. ${ }^{38}$ Seja como for, a questão fundamental relativa ao produtivismo consiste em saber como ele impacta uma universidade que sempre se orgulhou por fundar-se na isonomia.

Não se trata de estabelecer um contraponto entre presente maculado e idade de ouro. Conquanto parte expressiva dos profissionais dedicados aos estudos históricos seja consciente da importância da distinção entre o público e o privado, nunca foram desconhecidas denúncias de fraudes em concursos de docentes ou em processos equivalentes. Da mesma forma, sempre houve queixa da distribuição desigual do trabalho, decorrente da acomodação deste ou daquele colega, e do oportunismo de quem, relegando a segundo plano a reflexão, preocupa-se intensamente em tornar-se um schollar-star. José Arthur Giannotti tratou questões correlatas em livro de 1986, denominado A universidade em ritmo de barbárie. A primeira frase do texto é categórica: "Na barbárie se está atolado até o pescoço" ${ }^{39}$ Há, em meio às diversas análises propostas pelo filósofo, figura central do importante Seminário Marx, três elementos que aqui merecem destaque. O primeiro deles abarca a complexa relação entre civilização e barbárie, numa perspectiva dialética e crítica a certas leituras iluministas:

\footnotetext{
${ }^{38}$ Em 3 de setembro de 2012, o jornal Folha de S. Paulo lançou um caderno, logo transformado em selo, cujo título era "Ranking Universitário Folha" (RUF) que, como o nome indica, almejava avaliar as universidades brasileiras. Nas edições seguintes do periódico, teve início um rápido debate sobre a validade da iniciativa e dos critérios de ranqueamento, a respeito dos quais a ombudsman Suzana Singer, no dia 9, fez um balanço. Sua coluna terminava com as seguintes palavras sobre o RUF: “É uma boa notícia, porque a academia, que não gosta de avaliações e odeia comparações, precisa ser chacoalhada de tempos em tempos". Diga-me onde estudas... Folha de S. Paulo, Caderno Poder, p. A7. Pode ser que os acadêmicos odeiem avaliações e comparações; é algo a ser melhor estudado. Para entender o fenômeno, seria preciso ter sido avaliado no vestibular, no ingresso no mestrado e no doutorado, nas bancas de qualificação, dissertação e tese, na apresentação de artigos e de projetos visando a obtenção de recursos, no Coleta etc. Isso tudo acompanhado de medo, insegurança e dúvidas sobre a relevância do que se faz. A respeito do RUF, mencione-se que o selo, desde o seu lançamento, tem aparecido recorrentemente em propagandas de página inteira na própria Folha de S. Paulo, atestando a suposta qualidade de certas universidades privadas.

${ }^{39}$ GIANNOTTI, José Arthur. A universidade em ritmo de barbárie. $3^{\text {a }}$ ed. São Paulo: Brasiliense, 1987, p. 9.
} 
REVISTA DE HISTÓRIA

SÃO PAULO, N 169 , p. 255-290,

JULHO / DEZEMBRO 2013
Marco Antonio Silveira

História e política: a historiografia colonial entre a crítica e a responsabilidade (1989-2010)

Aqui reside o processo civilizatório, civilização significando um conjunto de práticas transculturais que integram indivíduos num único complexo articulado como segunda natureza. Não consiste, pois, na avalanche da razão ou no seu trabalho de formiga cimentando pensamento a pensamento, educando os indivíduos na prática do silogismo. Graças a isso, as condutas estariam cada vez mais próximas do pensar, como se fossem o decalque dele. Pelo contrário, armam-se como grandes sujeitos automáticos combinando coisas e pessoas por alguma de suas propriedades eminentes, aglutinando e dilacerando objetos, impondo paradigmas às condutas e ligando pessoas aos mesmos conteúdos de informação. E nisso ao mesmo tempo civiliza e barbariza. ${ }^{40}$

O autor apresenta, portanto, uma interpretação voltada para a dimensão estrutural - sem ignorar, contudo, as abordagens atinentes à "descontinuidade das culturas e das teorias, a multiplicidade das histórias que escapam a um único fecho funcional e organicamente integrado ${ }^{\prime \prime 1}-$, capaz de salientar tanto o que agrega quanto o que desagrega. O segundo elemento envolve a crítica a modelos autóctones: a universidade "traduz suas experiências particulares na linguagem da civilização e da barbárie".

Com isso fica excluída de imediato aquela visão provinciana que a concebe tão-só como instituto de autoconhecimento e de formação de cidadãos totalmente autônomo, voltado para seu interior, construído para refinar as peculiaridades duma experiência nacional. Se a universidade não pode distanciar-se do saber do seu povo, cumpre esse destino participando dum processo bárbaro de civilização. É a maneira de sermos Ocidente, deste Ocidente em crise, global, fagocitando tudo, homogeneizando o mundo, mas abrindo lacunas por onde podem infiltrar-se experiências particulares. Estas, contudo, só perdurarão e ganharão sentido se forem traduzidas nessa aventura universal. ${ }^{42}$

Trata-se de análise que busca conjugar o interno e o externo, compreendendo-os como inextricáveis. Algumas palavras - tais como "fagocitando" e "homogeneizando" - soam categóricas demais, pesando sobre elas a dúvida a respeito de concepções teleológicas ou apocalípticas. A mesma sensação se apresenta em outros trechos, como aquele em que se diz: "E não há alternativas para a cultura contemporânea". ${ }^{43}$ Porém, o substantivo "lacunas" e o verbo "infiltra-se" indicam a retomada de um aspecto caro ao Seminário Marx: não se pode separar a compreensão dos fenômenos internos da investigação

\footnotetext{
${ }^{40}$ GIANNOTTI, José Arthur. A universidade em ritmo de barbárie. $3^{\text {a }}$ ed. São Paulo: Brasiliense, 1987, p. 12-3.

${ }^{41}$ GIANNOTTI, José Arthur. A universidade em ritmo de barbárie. $3^{\text {a }}$ ed. São Paulo: Brasiliense, 1987, p. 9.

42 GIANNOTTI, José Arthur. A universidade em ritmo de barbárie. $3^{a}$ ed. São Paulo: Brasiliense, 1987, p. 19-20.

43 GIANNOTTI, José Arthur. A universidade em ritmo de barbárie. $3^{\text {a }}$ ed. São Paulo: Brasiliense, 1987, p. 22.
} 
REVISTA DE HISTÓRIA

SÃO PAULO, N ${ }^{\circ} 169$, p. 255-290,

JULHO / DEZEMBRO 2013
Marco Antonio Silveira

História e política: a historiografia colonial entre a crítica e a responsabilidade (1989-2010)

da dinâmica externa. Os pesquisadores podem discutir incansavelmente se a economia colonial era capitalista ou não, mas é difícil negar que o fluxo tecnológico e não regulamentado de capitais sem fronteira barbariza hoje a vida de milhões de pessoas no mundo, inclusive no Brasil. Seria um crime metodológico, ou uma ofensa anacrônica, partir da experiência atual e perguntar, salvaguardando-se as devidas diferenças qualitativas e quantitativas, se a inserção da América portuguesa nos circuitos mercantis da Idade Moderna, com suas dívidas sempre pendentes, não resultava em constrangimentos sofridos na carne por indivíduos inseridos em diferentes grupos sociais?

O terceiro elemento a ser destacado concerne ao contraponto entre o "poder acadêmico" e o "populismo" ou "poder sindical" que, desprezando a centralidade do mérito e recorrendo a um igualitarismo capenga, corrói as condições de produção do conhecimento:

O poder acadêmico é um chapéu de três bicos - difícil é articular os fios que ligam as três pontas, principalmente reconhecer que, neste jogo, nem todos são iguais. O mais experiente lidera e abre caminhos para o pesquisador aprendiz, o sábio ensina o estudante e o funcionário competente mostra aos recém-chegados como se monta uma pesquisa ou se põe em andamento a administração. Não existe poder acadêmico sem hierarquia de méritos. Neste jardim só entra quem souber geometria. ${ }^{44}$

Nesse ponto, a concepção de Giannotti acerca da universidade toma como base a autoridade - concebida como algo distinto dos estratagemas que, mobilizando meios de propaganda, multiplicam efeitos de visibilidade de um mérito que não é mérito. Três elementos decisivos, portanto: dialética entre civilização e barbárie, dialética entre interno e externo, e valorização da autoridade acadêmica.

É possível questionar as opções adotadas pelo filósofo em seu livro, perguntando-se em que medida elas seriam ou não positivas no tratamento das distorções sentidas no interior das universidades e em uma sociedade tão desigual como a brasileira. Seria também importante - embora tal tarefa não se mostre factível neste artigo - tentar reconstituir o caminho que conduziu Giannotti da reflexão sobre a universidade, em 1986, à defesa, em 2001, da existência de uma "zona de amoralidade" na política, justamente num contexto em que o presidente Fernando Henrique encontrava-se sob fortes acusações de patrocinar o fisiologismo. Na ocasião, o filósofo publicou,

\footnotetext{
${ }^{44}$ GIANNOTTI, José Arthur. A universidade em ritmo de barbárie. 3 a ed. São Paulo: Brasiliense, 1987, p. 68.
} 
REVISTA DE HISTÓRIA

SÃO PAULO, N 169 , p. 255-290,

JULHO / DEZEMBRO 2013
Marco Antonio Silveira

História e política: a historiografia colonial entre a crítica e a responsabilidade (1989-2010)

no jornal Folha de S. Paulo, um artigo chamado "O dedo em riste do jornalismo moral", que iniciava com os seguintes parágrafos:

Mais do que moral, acusar de imoral publicamente uma pessoa pública é ato político. Na medida em que a política, entre muitas coisas, consiste numa luta entre amigos e inimigos, ela pressupõe a manipulação do outro, desde logo suporta, portanto, certa dose de amoralidade. Não há política entre santos, mas já existe entre sábios, pois, embora devam discutir até o convencimento de todos, até chegar ao consenso e pronunciar uma verdade relativa, para isso precisam disputar recursos escassos, de sorte que alguns ficam privilegiados no processo de provar suas teses.

No entanto, é particularmente na democracia, quando os interesses gerais e comuns são discutidos até que se decida pela maioria, tornando legítima a ação executiva, que se percebe com nitidez sua zona cinzenta de amoralidade. ${ }^{45}$

A abordagem de Giannotti parecia ter relações com o problema da linguagem como um todo, já que não deixou de mencionar no texto Ludwig Wittgenstein. Se esse é o caso, a comparação traz desdobramentos interessantes: uma vez que toda linguagem é caracterizada por ambiguidades típicas de seu uso social, deixando margem para interpretações distintas perpassadas pela correlação de forças, o mesmo valeria para o jogo político. Porém, uma ressalva a essa hipótese implica outras consequências: sendo qualquer linguagem o exercício prático dos significados, ela não pode estar dissociada da moral. Essa é uma crítica dirigida à realpolitik ou às razões de Estado - devendo-se mencionar que a referência de Giannotti à "luta entre amigos e inimigos" é tirada de Carl Schmitt. Nesse sentido, em vez de avaliar os dilemas do governo fernandista em termos de uma "zona cinzenta de amoralidade" - atitude que, no limite, poderia naturalizar a fisiologia -, a questão talvez se tornasse mais clara se tratada como conflito ético. Se a ética abarca o que se deve fazer - os princípios morais -, o que se quer fazer - a vontade política - e o que se pode fazer - o princípio de realidade -, o enfrentamento de seus dilemas é sempre problemático. Dessa forma, Giannotti, se desejasse defender Fernando Henrique, poderia dizer que ele vivia, como governante, uma sucessão de dilemas éticos, pois, desejando promover o que considerava o melhor para o país, tinha de lidar com práticas políticas arcaicas e com estratégias ferozes do capital estrangeiro, capazes de pôr em xeque os seus próprios princípios. Tais dilemas éticos não seriam, evi-

\footnotetext{
${ }^{45}$ GIANNOTTI, José Arthur. O dedo em riste do jornalismo moral. Folha de S. Paulo, 17 de maio de 2001, Tendências/Debates, p. A3.
} 
REVISTA DE HISTÓRIA

SÃO PAULO, N ${ }^{\circ} 169$, p. 255-290,

JULHO / DEZEMBRO 2013
Marco Antonio Silveira

História e política: a historiografia colonial entre a crítica e a responsabilidade (1989-2010)

dentemente, exclusividade de Fernando Henrique, e constituem mesmo um grande ponto de interrogação para todos os acadêmicos adeptos do lulismo. De qualquer maneira, a diferença entre ambas as abordagens está no fato de que, enquanto a "zona de amoralidade" pode naturalizar a fisiologia e a violência, o reconhecimento dos dilemas éticos exige a responsabilização do governante pelas decisões tomadas visando sua resolução.

Seja como for, a análise de Giannotti sobre a universidade almejava encaminhar alguns de seus problemas recorrendo ao mérito e à autoridade, princípios que não implicam necessariamente desdobramentos autocráticos. Não é como recusa à valorização do mérito ou como defesa do "populismo" e do "corporativismo" que o princípio de isonomia se apresenta. A isonomia - presente no fato de todos os docentes de um departamento poderem tomar assento em sua assembleia e partilharem as mesmas condições políticas - sempre esteve vinculada à valorização da liberdade de pensamento. $\mathrm{O}$ reconhecimento das condições isonômicas não significa, pois, desconhecer as diferenças de mérito intelectual ou reduzi-las ao assembleísmo. De fato, a existência de garantias institucionais para o exercício do livre pensamento geralmente desconhecida em universidades privadas - é algo indispensável para que o respeito à autoridade intelectual não se transforme na autocracia representada por orientandos transformados em fiéis seguidores. É nesses termos, inclusive, que se pode lidar com o tema da partilha das cansativas tarefas de gestão. Os pesquisadores discutem de modo exaustivo se vigorou ou não, no Império português, uma governação compartilhada, mas parecem ter pouco interesse em compartilhar a gestão universitária e entendê-la como um tipo de exercício isonômico de governo.

A pior perversão possível consistiria em deixar de pensar o problema nas condições colocadas pelos princípios de mérito, isonomia e solidariedade, colocando-o à mercê do produtivismo. Nesse caso, a universidade estaria apenas desfechando mais um capítulo do que Claudine Haroche denominou de "sociedade de desconfiança". A autora, discutindo as mudanças ocorridas nas últimas décadas, assinala o papel da avaliação no conjunto de mecanismos através dos quais o controle se dissemina e se interioriza, apagando as singularidades, corroendo os sentidos e causando a sensação de estar sendo vigiado pelos colegas.

A avaliação incessante, transformada em "instrumento" de controle contínuo que ignora, quando não despreza, o indivíduo isolado na sua singularidade, depende dessa desconfiança e a reforça. Ela tenta reduzir a parte de desconhecido, reconduzindo-a doravante à cifra, à quantificação, à linguagem formal da governança, sem conteúdo e substância nas sociedades onde os funcionamentos e as identidades são fragmentados, 
REVISTA DE HISTÓRIA

SÃO PAULO, N 169 , p. 255-290,

JULHO / DEZEMBRO 2013
Marco Antonio Silveira

História e política: a historiografia colonial entre a crítica e a responsabilidade (1989-2010)

misturados, múltiplos, instáveis, difusos e incertos. O valor doravante cifrado tende a ser desprovido de conteúdo. ${ }^{46}$

Assim, pode-se retornar à questão colocada no início desta seção: como os acadêmicos ligados à História fazem a bodega funcionar? Eles, como trabalhadores da bodega, têm investido um grande esforço na formação de alunos de graduação e pós-graduação, bem como na realização de pesquisas e na dedicação ao crescimento das instituições superiores de ensino. Também como trabalhadores têm sido atravessados por mecanismos de dominação que causam sua exaustão física e psíquica, e corroem a solidariedade que poderia aliviar um cotidiano penoso. Esses historiadores, em suas próprias experiências de vida, demonstram que a inserção em determinados modelos de ordenamento social e a busca por reconhecimento podem constituir um veneno que ao mesmo tempo gratifica e mata. Talvez, nos próximos anos, continuem a aparecer centenas de dissertações, teses, artigos e livros tratando das estratégias bem-sucedidas de ascensão social durante o Antigo Regime luso, mas tais trabalhos serão feitos à custa de grande sofrimento. ${ }^{47}$ Por outro lado, os acadêmicos atuam também como proprietários da bodega - especialmente quando naturalizam a realpolitik em detrimento da valorização da universidade como espaço público, fingem desconhecer a relação entre política e gestão, fixam-se obcecadamente nas ilusões de uma carreira individualmente bem-sucedida e deixam de enfrentar os dilemas éticos atinentes às várias formas de governação.

Nesse sentido, seria metodologicamente criminoso perguntar se o fato de inúmeros historiadores subordinarem-se a determinadas formas de dominação e reproduzirem práticas conservadoras no interior das próprias

\footnotetext{
${ }^{46}$ HAROCHE, Claudine. O inalienável em uma sociedade de desconfiança. Educação e Pesquisa. São Paulo, v. 37, n. 3, setembro a dezembro de 2011, p. 664.

${ }^{47}$ De acordo com o médico Sérgio Arthuro, doutor em psicobiologia, "A imagem de nós cientistas no senso comum, como estereotipada por Einstein, é que somos meio loucos. De fato, como revelado recentemente pela revista Nature, parece que realmente não temos uma boa saúde mental, dada a alta ocorrência de depressão entre pós-graduandos e pós-doutorandos". Lembrando que, "Segundo o texto, boa parte dos estudantes de pós-graduação que desenvolvem depressão foram ótimos estudantes na graduação", Arthuro explica para o público leigo: "Os pós-graduandos são os estudantes de mestrado e de doutorado, enquanto os pós-doutorandos são os recém-doutores em aperfeiçoamento, que ainda não conseguiram um emprego estável. Os pós-doutorandos são comuns há muito tempo nos laboratórios da Europa e dos Estados Unidos, já no Brasil este é um fenômeno recente". ARTHURO, Sérgio. Depressão na pós-graduação e pós-doutorado. Blog da Sociedade Brasileira de Neurociências e Comportamento. 25 de outubro de 2012; blog.sbnec.org.br/2012/10/depressao-na-pos-graduacao-e-pos-doutorado.
} 
REVISTA DE HISTÓRIA

SÃO PAULO, N ${ }^{\circ} 169$, p. 255-290,

JULHO / DEZEMBRO 2013
Marco Antonio Silveira

História e política: a historiografia colonial entre a crítica e a responsabilidade $(1989-2010)$

universidades tem algo a ver com a luz lançada obsessivamente sobre a busca por distinção no passado colonial? A maioria da antiga esquerda acadêmica, que migrou para a frágil ilustração do PSDB ou permaneceu ligada ao novo PT, não estaria, em alguma medida, caminhando para a direita ao aceitar doses cada vez maiores do arcaico pragmatismo na luta política? Não se estaria constituindo na universidade uma saída de conciliação entre a ideologia - com o perdão do suposto anacronismo - e o pragmatismo, entre a isonomia e o ranking, que se expressaria na valorização de temas ligados ao desejo de adesão à ordem ${ }^{48}$ Haveria, a esse respeito, e apesar das inúmeras diferenças sociológicas e históricas, algum paralelo entre a situação brasileira e aquela experimentada por países como Portugal e Espanha?

\section{Reponsabilidade e esquecimento}

Luiz Roberto Salinas Fortes foi docente da Universidade de São Paulo, tendo passado pela sofrida e angustiante experiência imposta pelos porões da ditadura. Registrou-a em Retrado calado, livro do qual foi retirada a epígrafe deste artigo. ${ }^{49}$ Em seu depoimento, aparecem elementos comuns a testemunhos deixados por quem viveu acontecimentos traumáticos: a sensação de impotência, a busca de sentido para uma experiência marcadamente violenta, o medo de que o sofrimento vivido seja enterrado no emaranhado da história, o questionamento sobre a insignificância de si, o apelo pela justiça - tudo isso sintetizado em uma dura afirmação: "a dor é séria”. Relatos como o de Salinas Fortes são, ao mesmo tempo, um desafio e uma possibilidade para o historiador: um desafio porque demandam cuidados metodológicos quanto ao tratamento da memória como fonte; possibilidade porque abrem trilhas pelas quais o sentido de quem sofreu a dor na carne e na mente enriquece a escrita historiográfica. Nesse sentido, seu significado distancia-se dos receios de Jacob Gorender na crítica que fez, no debate ufopiano, ao subjetivismo. Por outro lado, depoimentos dessa natureza, ao indicarem a complexidade da dor e da experiência violenta, exigem que os historiadores sejam eticamente cuidadosos. Em especial quando faltam tais testemunhos, ou

\footnotetext{
${ }^{48}$ Como lembra Singer: "Embora seja um equívoco desconhecer que o governo Lula cumpriu parte do programa original do partido ao estimular o mercado interno de massas, é verdade que, desconectados de postura anticapitalista, os ganhos materiais conquistados levam água para o moinho do estilo individualista de ascensão social, embutindo valores de competição e sucesso no lulismo", op. cit., p. 119.

${ }^{49}$ FORTES, Luiz Roberto Salinas. Retrado calado. $2^{\text {a }}$ edição. São Paulo: Cosac Naify, 2012, p. 118.
} 
REVISTA DE HISTÓRIA

SÃO PAULO, N 169 , p. 255-290,

JULHO / DEZEMBRO 2013
Marco Antonio Silveira

História e política: a historiografia colonial entre a crítica e a responsabilidade (1989-2010)

quando são filtrados e fragmentados pelas fontes oficiais, a descrição dos dilemas da dor é comumente substituída por um tortuoso sigilo. Em condições tais, bastante recorrentes no estudo da escravidão, ainda que sejam envidados todos os esforços metodológicos e interpretativos, resta a necessidade de se evitarem afirmações categóricas demais sobre a adesão à ordem vigente. Não se deseja, com essa observação, retomar a armadilha, tão presente, por exemplo, na Revolução Francesa, de justificar formas de ação - algumas delas cruéis - recorrendo-se à compaixão gerada pelo sofrimento do povo. A compaixão é uma arma perigosa justamente pelo potencial que tem de deslocar rapidamente a política e a reflexão. Dessa forma, ela se distingue da solidariedade. ${ }^{50}$ Em boa parte, as tensões entre as diferentes interpretações e os diferentes modelos adotados pelos historiadores, indo além das análises propriamente historiográficas, são perpassadas pelo medo do esquecimento. Colegas de ofício de distinta orientação não constituem revisionistas ou xiitas, mas tendem a sofrer, cada um a sua maneira, o peso que advém do perigo de se soterrar aquilo que para muita gente no passado - inclusive o escravista - não deveria ser esquecido. Daí o importante tema da responsabilização dos intelectuais frente às injustiças das sociedades pretéritas ou daquelas atuais. É nesse sentido que se podem avaliar as contribuições de Marx e de outros pensadores. É preciso criticá-los sempre - pois nenhum pensamento é imune a equívocos, preconceitos e apropriações perversas -, mas também perguntar-se sobre o compromisso que nos legaram. Conjurar espectros não parece ser uma boa saída. E os historiadores criaram seus modos próprios de fazê-lo, utilizando-se da crítica seletiva ao anacronismo, de fórmulas expressas num vocabulário de exclusão e de estratégias de busca de hegemonia. Uma historiografia tradicional, aliás, poderia enviar à ideia de que as novas gerações têm o que aprender com as antigas, a despeito de toda a fragmentação do mundo moderno - em vez de referir pejorativamente o que ficou para trás, o que está ultrapassado ou o que não se coaduna com a "nova ordem mundial". O presente não é propriamente um ser, uma essência, já que cada ato é atravessado pela assombração da memória e pela sugestão do futuro. Conjurar a memória e o pensamento significa apenas fingir que o presente é uma coisa que existe em si mesma, e que o futuro não pode ser sugerido ou inventado. Não riam, por favor, pois a dor é séria.

Recebido: 15/03/2013 - aprovado: 28/06/2013.

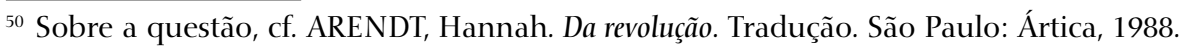

